\title{
Structural mapping based on potential field and remote sensing data, South Rewa Gondwana Basin, India
}

\author{
Swarnapriya Chowdari ${ }^{1}$, Bijendra Singh ${ }^{1,2, *}$, B Nageswara RaO ${ }^{1}$, \\ Niraj Kumar ${ }^{1}$, A P Singh ${ }^{1}$ and D V ChandraseKhar ${ }^{1, * *}$ \\ ${ }^{1}$ Gravity and Magnetic Studies Group, CSIR-National Geophysical Research Institute, Hyderabad 500 007, India. \\ ${ }^{2}$ Indian Institute of Geomagnetism, Navi Mumbai, Maharashtra 410 218, India. \\ *Corresponding author.e-mail: bsingh_ngri@yahoo.co.in
}

MS received 23 August 2016; revised 3 March 2017; accepted 5 March 2017; published online 31 August 2017

Intracratonic South Rewa Gondwana Basin occupies the northern part of NW-SE trending Son-Mahanadi rift basin of India. The new gravity data acquired over the northern part of the basin depicts WNW-ESE and ENE-WSW anomaly trends in the southern and northern part of the study area respectively. 3D inversion of residual gravity anomalies has brought out undulations in the basement delineating two major depressions (i) near Tihki in the north and (ii) near Shahdol in the south, which divided into two sub-basins by an ENE-WSW trending basement ridge near Sidi. Maximum depth to the basement is about $5.5 \mathrm{~km}$ within the northern depression. The new magnetic data acquired over the basin has brought out ENE-WSW to E-W trending short wavelength magnetic anomalies which are attributed to volcanic dykes and intrusive having remanent magnetization corresponding to upper normal and reverse polarity (29N and 29R) of the Deccan basalt magnetostratigrahy. Analysis of remote sensing and geological data also reveals the predominance of ENE-WSW structural faults. Integration of remote sensing, geological and potential field data suggest reactivation of ENE-WSW trending basement faults during Deccan volcanism through emplacement of mafic dykes and sills. Therefore, it is suggested that South Rewa Gondwana basin has witnessed post rift tectonic event due to Deccan volcanism.

Keywords. South Rewa Basin; remote sensing; gravity; magnetic; lineament; structures; dykes.

\section{Introduction}

The geophysical data are invariably combined with geological and remote sensing data for a better understanding of the subsurface structures in a variety of investigations, such as mineral and energy resources, environmental characterizations, groundwater and geohazard studies. The integration of geological, remote-sensing, and geophysical

\footnotetext{
${ }^{* *}$ Deceased.
}

data aids in the detection and geological interpretation of the structural features and has the potential of constraining quantitative details and reducing the ambiguity of geological interpretation (Lunden et al. 2001; Lamontagne et al. 2003; Chen and Zhou 2005; Yassaghi 2006). Geophysical methods in general and gravity and magnetic methods in particular are commonly used in the structural interpretation of sedimentary basins because of their better spatial resolution (Liu et al. 1996). South Rewa Gondwana basin preserves the large thickness of Permo-Trassic Gondwana sediments. 
Large number of scattered dykes/sills and flows of Deccan basalts of Cretaceous age intrude the sediments which is a serious problem in the delineation of subsurface structural details of the basin. The new gravity and magnetic $(\mathrm{G}-\mathrm{M})$ data was acquired during the year 2009 over the northern part of the basin to delineate the basin configuration as a part of hydrocarbon exploration program sponsored by oil industries (Bijendra Singh et al. 2009). G-M surveys revealed significant basement undulations, and inferred boundary and intrabasinal faults parallel to the Narmada-Son lineament. In order to understand the tectonic correlation of these faults, we carried out analysis of remote sensing data over the Son-Mahanadi basin. Here, we propose to carry out integration of the remote sensing data with potential field data to investigate the structural details of the basin architecture in order to comprehend the tectonic development of the basin. In this endeavor, we have utilized state of the art Geosoft 6.4.2 (GEOSOFT Oasis Montaj 2008) software for the analysis and interpretation of $\mathrm{G}^{-}$ $\mathrm{M}$ data and ERDAS IMAGINE 9.3 and ArcGIS 10 for the processing of remote sensing and GIS data.

The study area (figure 1) lies in the state of Madhya Pradesh with its eastern boundary coinciding with the interstate boundary of Chhattisgarh and Uttar Pradesh states. It covers a surface area of approximately $13,277 \mathrm{~km}^{2}$ covering Anuppur, Shahdol, Umariya, Sidi and Dindori districts of Madhya Pradesh. Topography of the study area and the adjoining region obtained from shuttle radar topographic mission (SRTM) (ftp://edcsgs9. cr.usgs.gov/pub/data/srtm) (figure 1) shows elevation that ranges approximately between 252 and $933 \mathrm{~m}$.

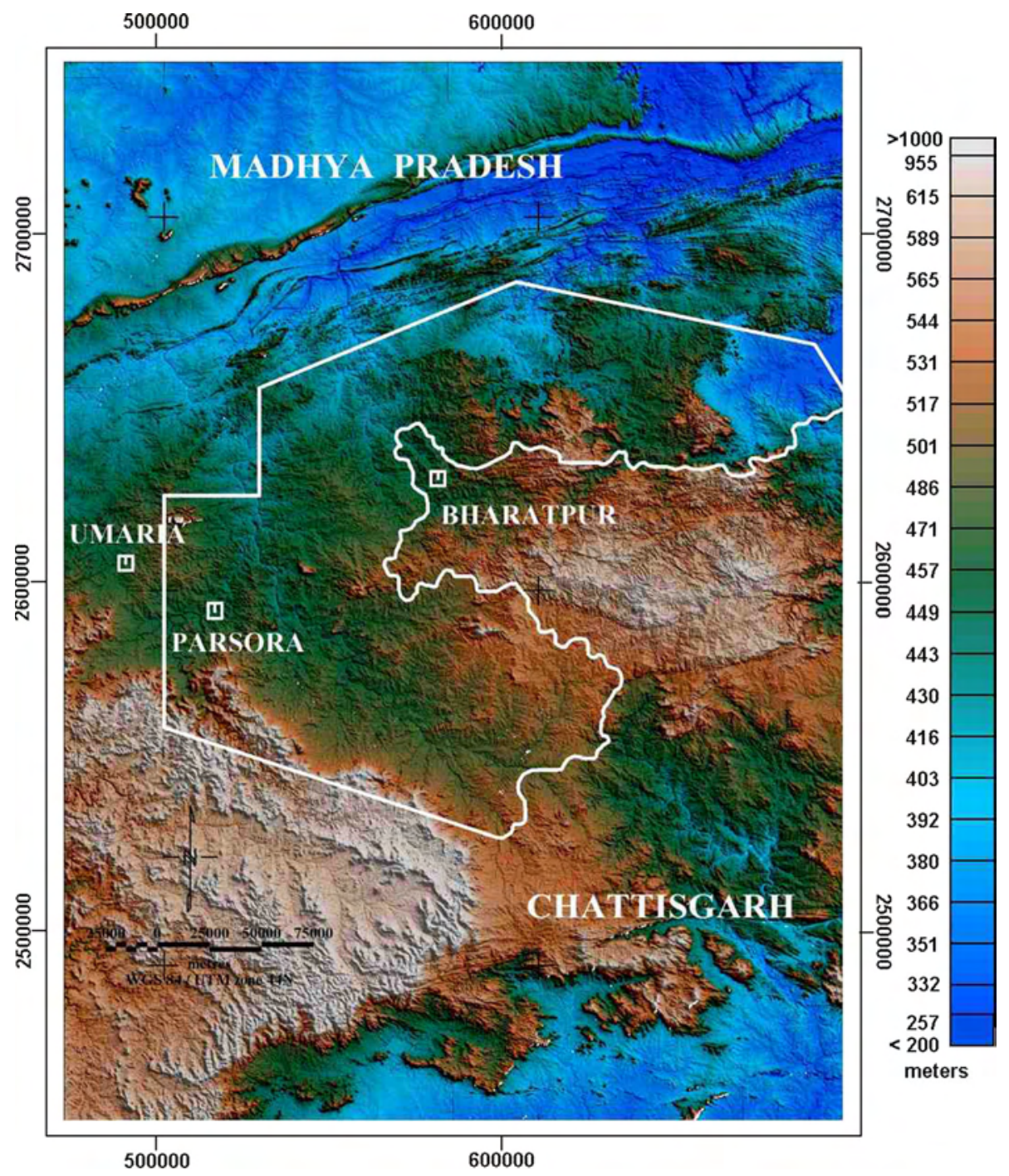

Figure 1. Location map of the study area and adjoinings, plotted on topographic map of the region obtained from shuttle radar topographic mission (SRTM). (ftp://edcsgs9.cr.usgs.gov/pub/data/srtm). 


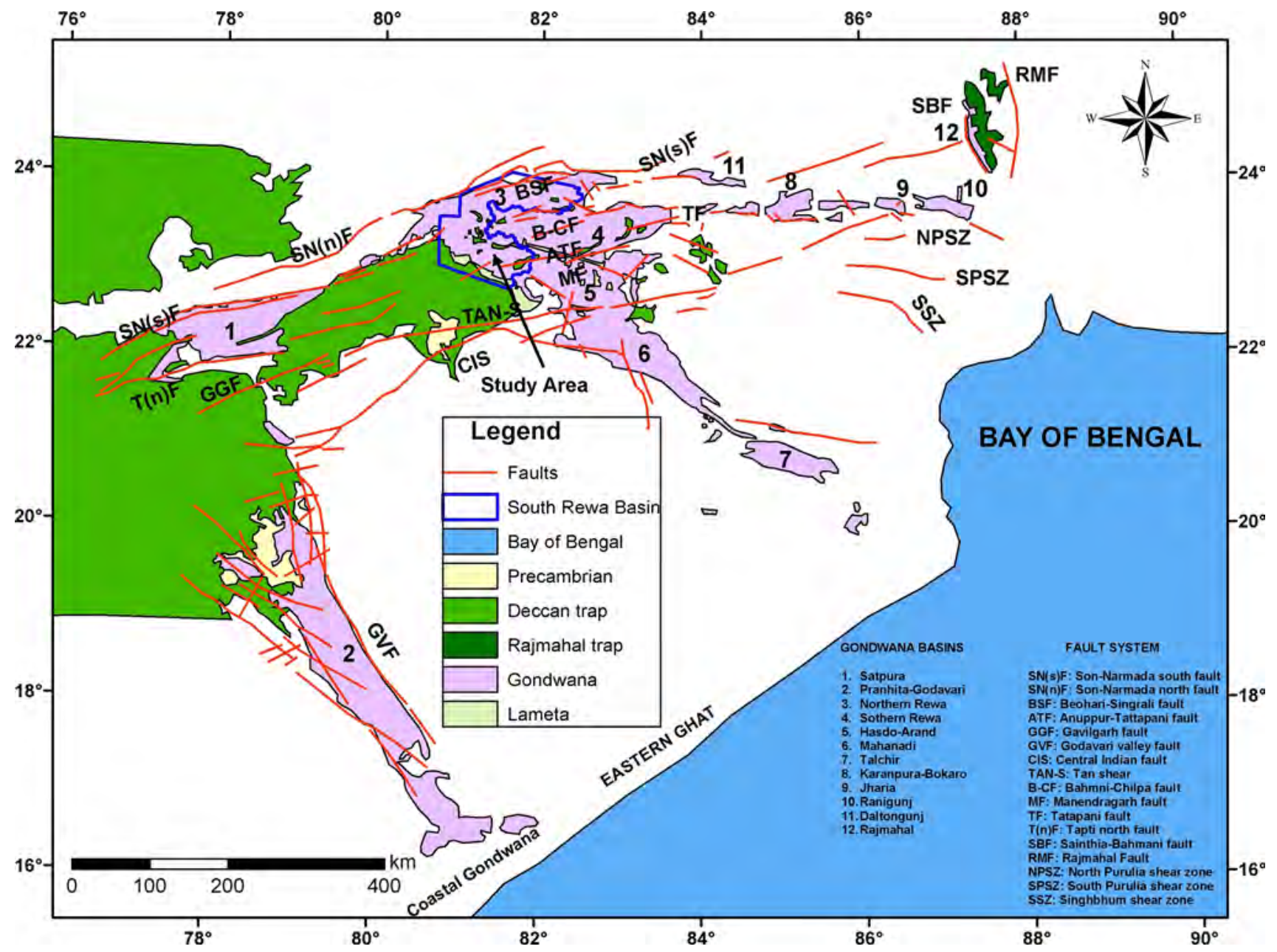

Figure 2. Map showing occurrences and distribution of Gondwana basins. Study area is marked in blue colour and the major faults and lineaments are marked in red colour associated with different Gondwana basins of peninsular India after Chakraborty et al. (2003).

\section{Geology and tectonics of the study area}

Intra cratonic Gondwana rift basins of the Indian Peninsular shield (figure 2) are exposed in the E-W trending Damodar-Koel and Satpura basins, and the NW-SE trending Son-Mahanadi, and Pranhita-Godavari grabens. These basins are typically bounded by normal faults that developed along the Precambrian lineaments during deposition, as well as affected by intrabasinal faults indicating fault-controlled synsedimentary subsidence. The patterns of the intrabasinal faults and their relationships with the respective basinbounding faults represent both extensional and strike-slip regimes (Chakraborty et al. 2003; Biswas 1999). Presence of Permo-Carboniferous glaciogenic deposits at the base of the individual basins demonstrates their development in response to a regional (global) tectonic event (Casshyap and
Tewari 1991; Veevers and Tewari 1995; Biswas 1999).

The South Rewa Basin (SRB), which is the region of present study, occupies the northern part of the NW-SE to WNW-ESE trending SonMahanadi graben (Chakraborty et al. 2003). It is elongated in ENE-WSW direction and covers an area of approximately $28,500 \mathrm{~km}^{2}$ of exposed Gondwana sediments. The detailed geological map of the region is shown in figure 3. Geologically, the basin is delimited by Umaria-Korar coalfield in the west, Deccan trap in the southwest, Mahanadi basin in the south, Precambrian basement in the southeast, east and north. Stratigraphically, the Lower Gondwana rocks deposited over the Precambrian basement consists of Talchir, Karharbari, Barakar, Barren measures and Raniganj formations. The lithology of these formations is normally shale, sandstone and coal seams. While 


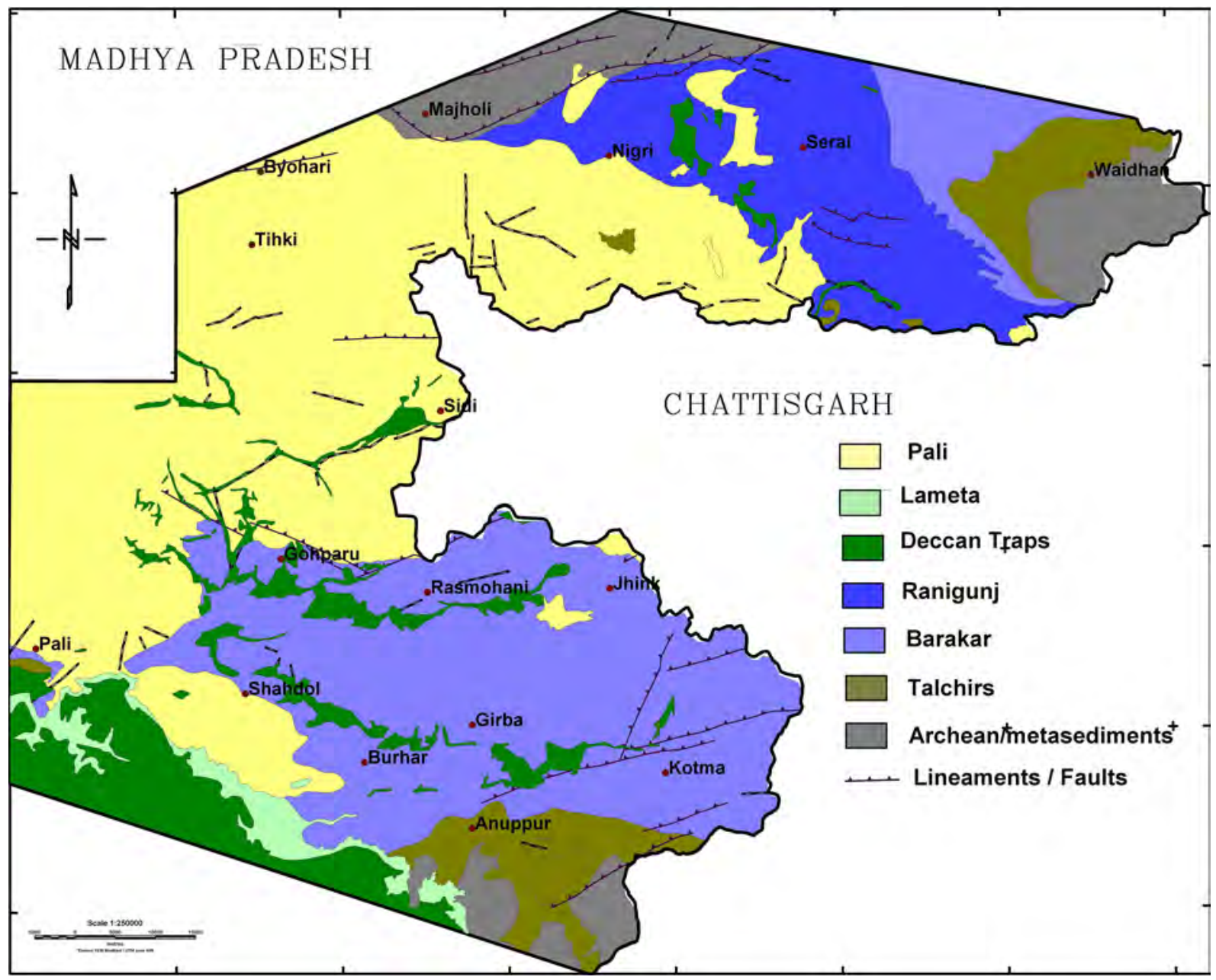

Figure 3. Detailed geological map with geological faults/lineaments of the study area.

the Upper Gondwana rocks of Lower Triassic to Lower Cretaceous age consists of Pali-Tihki, Parsora and Bansa-Chandia/Jabalpur formations. Lameta beds developed in southwestern part of the basin comprise of green sandstones, limestone, and calcareous clay and overly the Gondwana rocks. The southern part of the basin is covered by Deccan trap flows erupted during Upper Cretaceous/Palaeocene period. A large number of scattered outcrops of Deccan volcanics in the form of dykes, sills and flows are encountered throughout the basin, suggesting more widespread and extensive volcanic sheet, which might have eroded in due course of time (Lala et al. 2011). ${ }^{39} \mathrm{Ar} /{ }^{40} \mathrm{Ar}$ dating of some of these mafic dykes reported evidence of Deccan age (Lala et al. 2014). An exploratory well drilled by ONGC at Tihki within the survey block has established the stratigraphic correlation of Lower and Upper Gondwana sediments and encountered basalts. The stratigraphic sequence of rock formation encountered in Tihki well is shown in figure 4. The basement encountered at $3915 \mathrm{~m}$ is granite-gneiss.

The structural set up of the basin is controlled by pre-existing Dharwarian (NW-SE) and SonNarmada lineaments (ENE-WSW). A set of faults parallel to and along with the ENE-WSW trending Son-Narmada south fault bound the basin in the north defining the Malwa ridge while another set of ENE-WSW trending fault runs along the middle of the Rewa basin dividing it into northern and southern compartments (figure 2) (Raja Rao 1983; Agarwal et al. 1993). The ManendragarhPratappur basement ridge bounded by ENE-WSW trending faults separates the SRB from the HasdoArand basin in the south. These bounding faults consistently show evidence of strike-slip displacement (Raja Rao 1983; figure 2). There are two sets of intrabasinal faults, one making low angles to the basin boundaries in both clockwise and anticlockwise directions, and the other set is at high angles with trends varying from NNE-SSW 


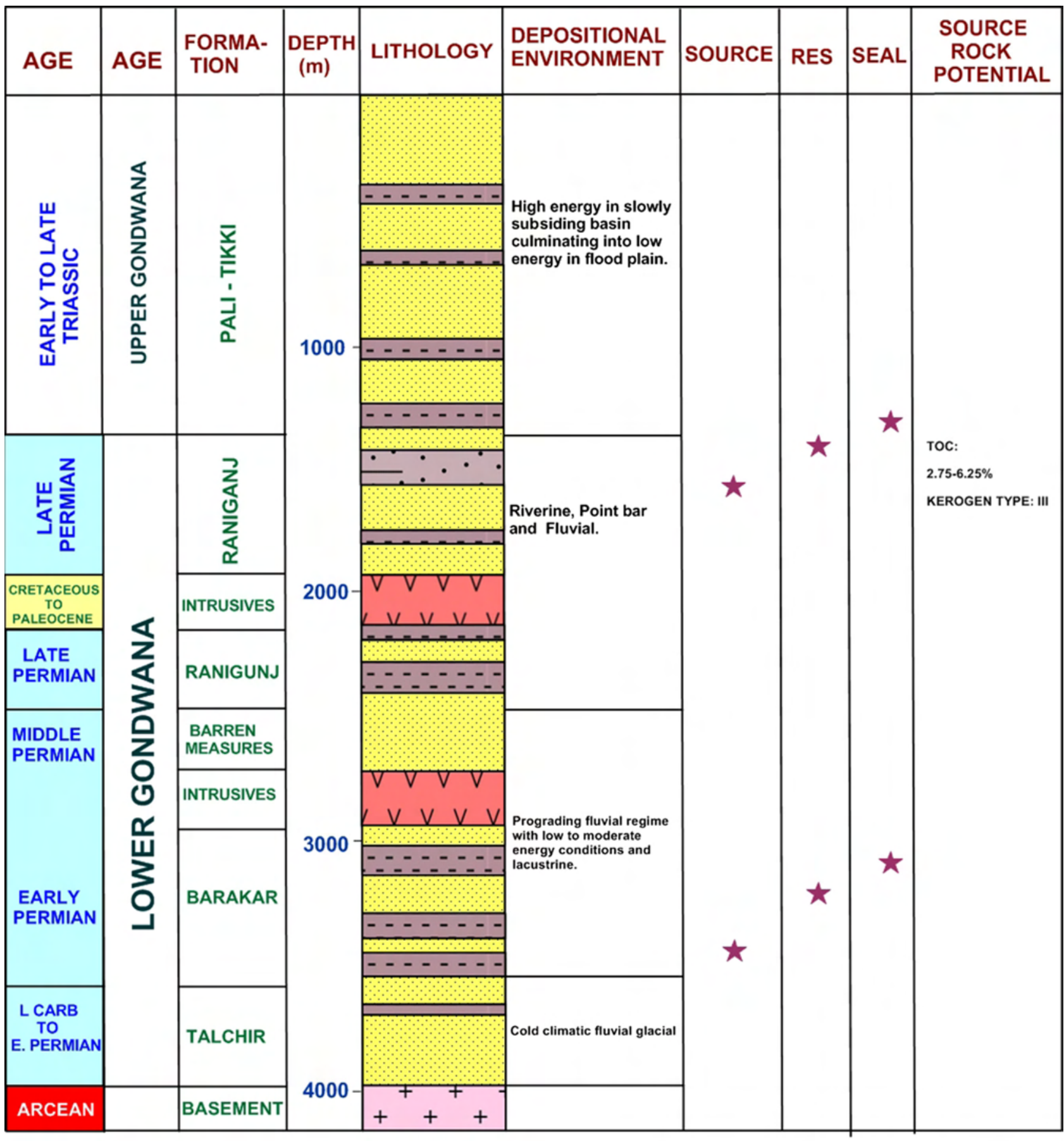

TD 4019(m)

\section{LEGEND}

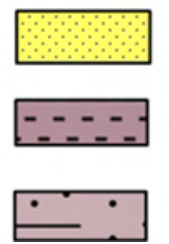

SAND / SILTSTONE

SHALE / CLAYSTONE

CARB. SHALE I COAL

INTRUSIVE (DOLERITE)

BASEMENT (GRANITE)

Figure 4. Lithostratigraphy of Tihki-1 well (after Jitendra Kumar et al. 2005). 
to NNW-SSE (Chakraborty et al. 2003; Raja Rao 1983). Evidence of strike-slip displacement along the ENE-WSW trending bounding faults at the northern and southern margin of the South Rewa basin and presence of intrabasinal cross faults suggests that the basins developed due to extension across pre-existing weak planes confined between two strike-slip faults oriented along the extension direction. Thus, SRB appears to be formed by both extensional and strike-slip regimes.

\section{The data}

A Landsat ETM+ images were processed and interpreted to identify geological structures and prepare a map of regional distribution of geological formations in the study area. The new gravity and magnetic data were used to validate the structures on the geological and remotely sensed imagery maps. The magnetic data has also provided subsurface locale of volcanic intrusive. The four different data types were integrated using the geographic information system (GIS) technique. A schematic diagram explaining the procedure of GM data processing and analysis for structural investigation adopted is presented in figure 5(a).

\subsection{Remote-sensing $(R S)$ data}

The application of remote sensing for mapping of regional structures has a long tradition (Bonham Carter 1989; Harris 1991; Fraser et al. 1997; Zeinalov 2000; Leech et al. 2003; Cengiz et al. 2006; Raharimahefa and Kusky 2006; Pereira et al. 2008). Remote sensing data offer enough scope for the mapping of linear features of geological interest, called lineaments, representing joints, fractures, and faults. The lineaments on the RS data can mainly be identified based on their linear nature, presence of moisture, alignment of vegetation, alignment of ponds, straight stream segments, etc.; however, the interpretation of fault is based on rocks on opposite sides, geological structures, land forms, drainage pattern and topographical features.

For investigating the present area, Landsat7 Level 1 Enhanced Thematic Mapper plus (ETM+) Data (Resolution $30 \mathrm{~m}$ ) was downloaded from USGS site http://earthexplorer.usgs.gov/. The images were mosaic-processed and analyzed to identify surface structural features, i.e., lineaments. The extracting criteria for lineaments and visual interpretation were based mainly on the image characteristics (tone and texture), lithological boundaries (rock units) and the geomorphological features (drainage patterns). Principal component analysis (PCA) was implemented to enhance the visual interpretation for revealing geological lineaments, thus increasing the possibilities for extracting useful geological information.

\subsubsection{Methodology for extracting the structural information}

Several image processing methods can be used for enhancing the geological structures. We have applied spatial domain filters especially high pass, edge detector, etc., for enhancing the structures using ERDAS EMAGINE 9.3 Software (The ERDAS IMAGINE 2008). A flow chart (figure 5b) shows the steps followed to delineate lineaments from RS data.

An edge represents discontinuities or a sharp change in the grey-scale value of a particular pixel at a point that might have some interpretation in terms of geological structure or relief (Mather 1993). We perform the edge enhancement by application of a high-pass filter, which emphasize the detailed high-frequency components of an image and de-emphasize the more general low-frequency information (Lillesand and Kiefer 2000). It is executed by detecting edges and then either by adding these back into the original image to increase contrast near an edge or by highlighting edges using saturated overlays on borders (Richards 1993). Principal component analysis (PCA) allows the redistribution of data in the original channels by means of a linear transformation of channel variables between the same number of new channels in such a manner that the images in the first three principal component images must contain most of the information in the N-band. The first three PCA bands were produced using all bands except the thermal and panchromatic bands (figure 6). The first three principal components contain $96.03 \%$ of the total variance of the ETM image. A total of 133 lineaments were extracted and mapped from the directional filters and PCA image with a mean lineament length of $10.03 \mathrm{~km}$ and a maximum lineament length of $86 \mathrm{~km}$. The Rose diagram shows two prominent lineament trends, i.e., ENEWSW as a main lineaments direction and NW-SE striking as a secondary lineaments direction. The ENE-WSW trend is predominant in the north 


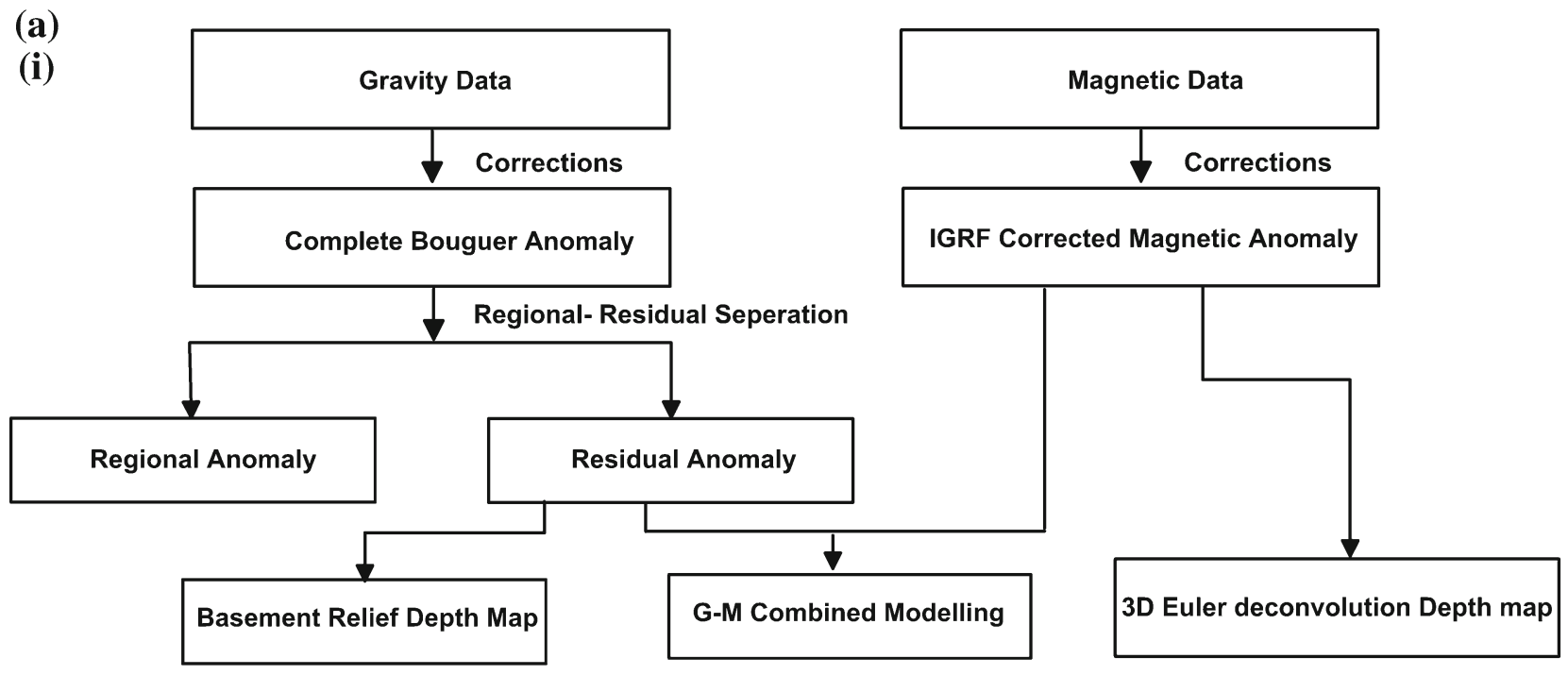

(ii)

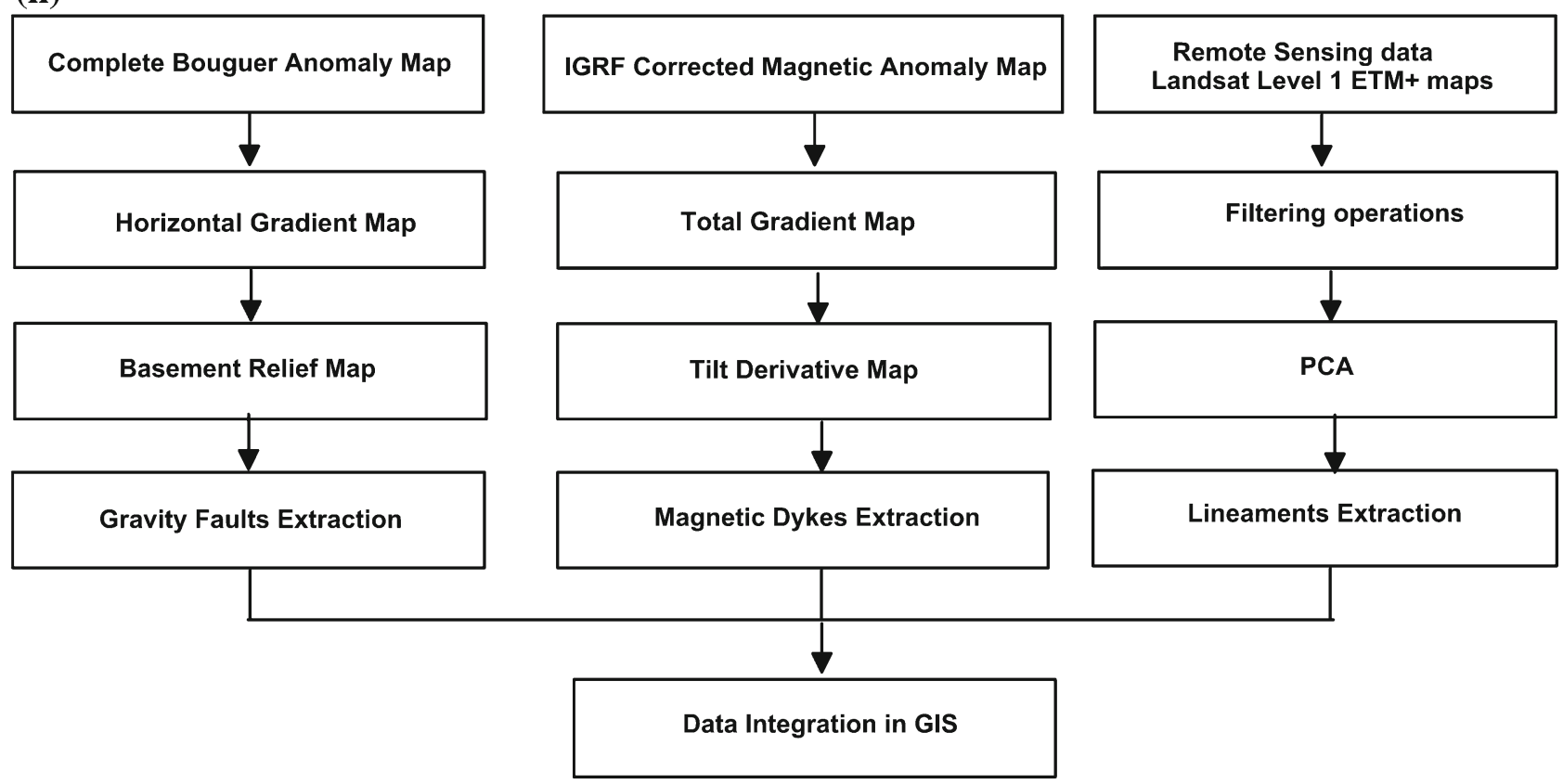

Figure 5(a). Schematic diagrams showing steps involved in (i) G-M data processing and (ii) G-M and RS data analysis for structural investigation.

and coincides with the ENE-WSW trending SonNarmada lineament in the north separating the Malwa ridge by the basin margin faults towards the north. It might also represent the intrabasinal faults. The NW-SE trending lineament represents basin boundary fault towards the south. The ENEWSW lineaments/faults inferred in the basin are grouped as Precambrian faults (Agarwal et al. 1993) and are defined as the margins of the Basin associated with Geological boundary faults, i.e., the northern and southern margins of the basin are Beohari- Singrauli and Anuppur-TattaPani faults.

\subsection{Gravity survey}

Gravity measurements were taken at 2500 locations with observations at $2 \mathrm{~km}$ interval along roads and tracks forming a station distribution of approximately one station per $2 \times 2 \mathrm{~km}^{2}$ grid. Since, large part of the area is covered by thick forest and steep hills; deviation from stated density distribution was inevitable at a number of places. During the present survey, one CG-5 (model \#113) and two LRG gravimeters (model \#G-1075, G1056)) having accuracy of $5 \mu \mathrm{Gal}$ and $0.01 \mathrm{mGal}$, 
(b)

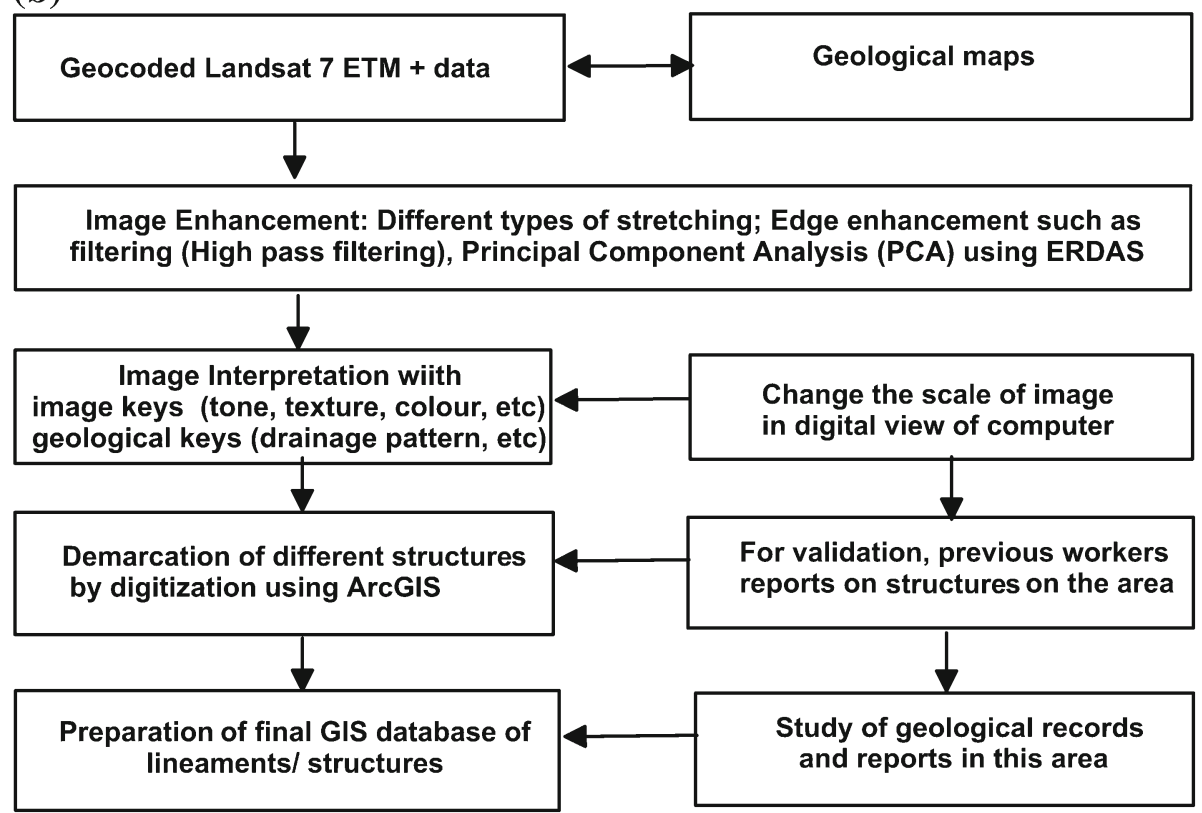

Figure 5(b). Flow chart describing steps for delineating lineaments from RS data.

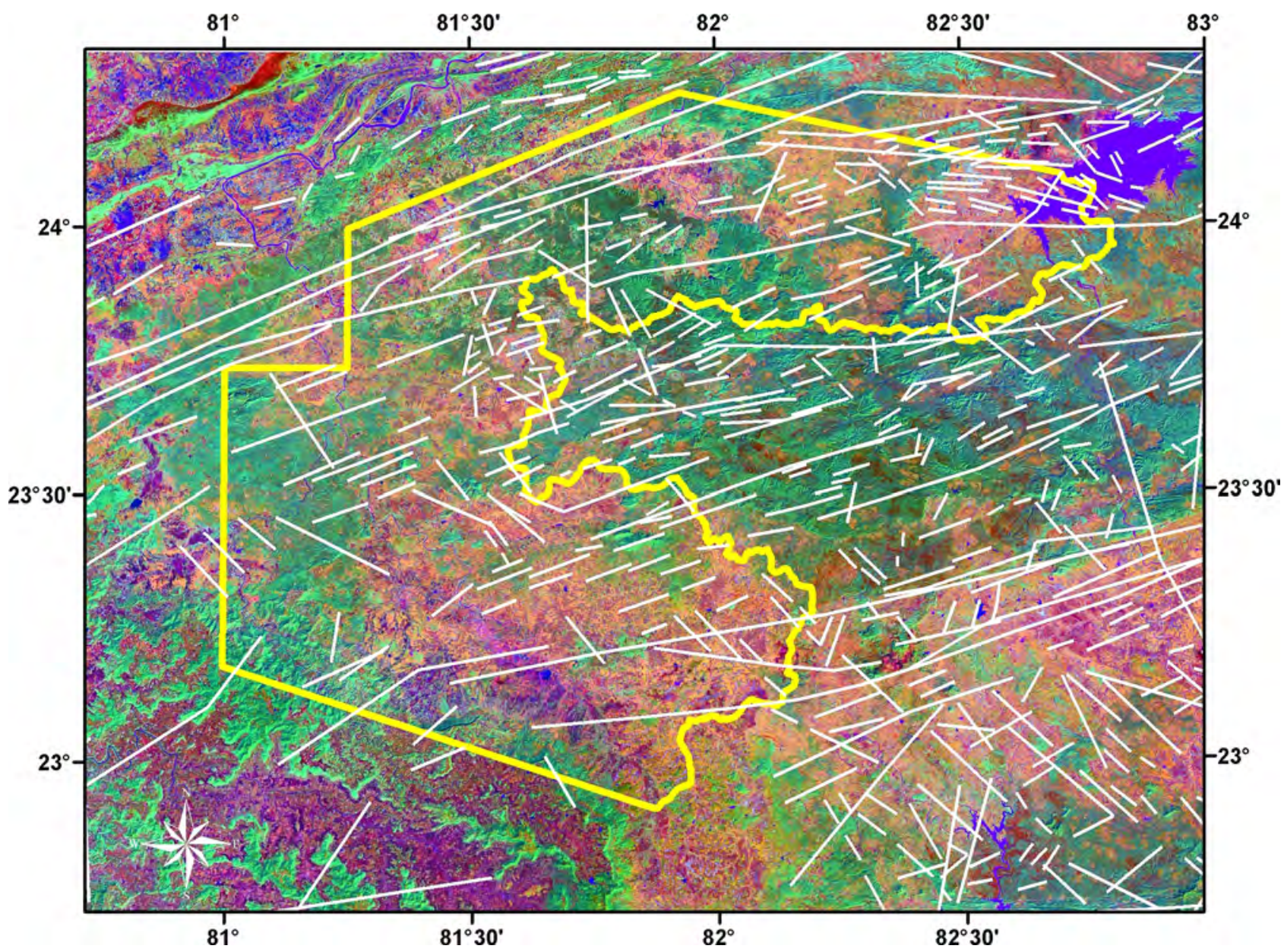

Figure 6. Processed remote sensing image from principal component analysis of PC1 (red), PC2 (green) and PC3 (blue) with lineaments drawn in white colour lines and boundary of study area marked in yellow colour line. 


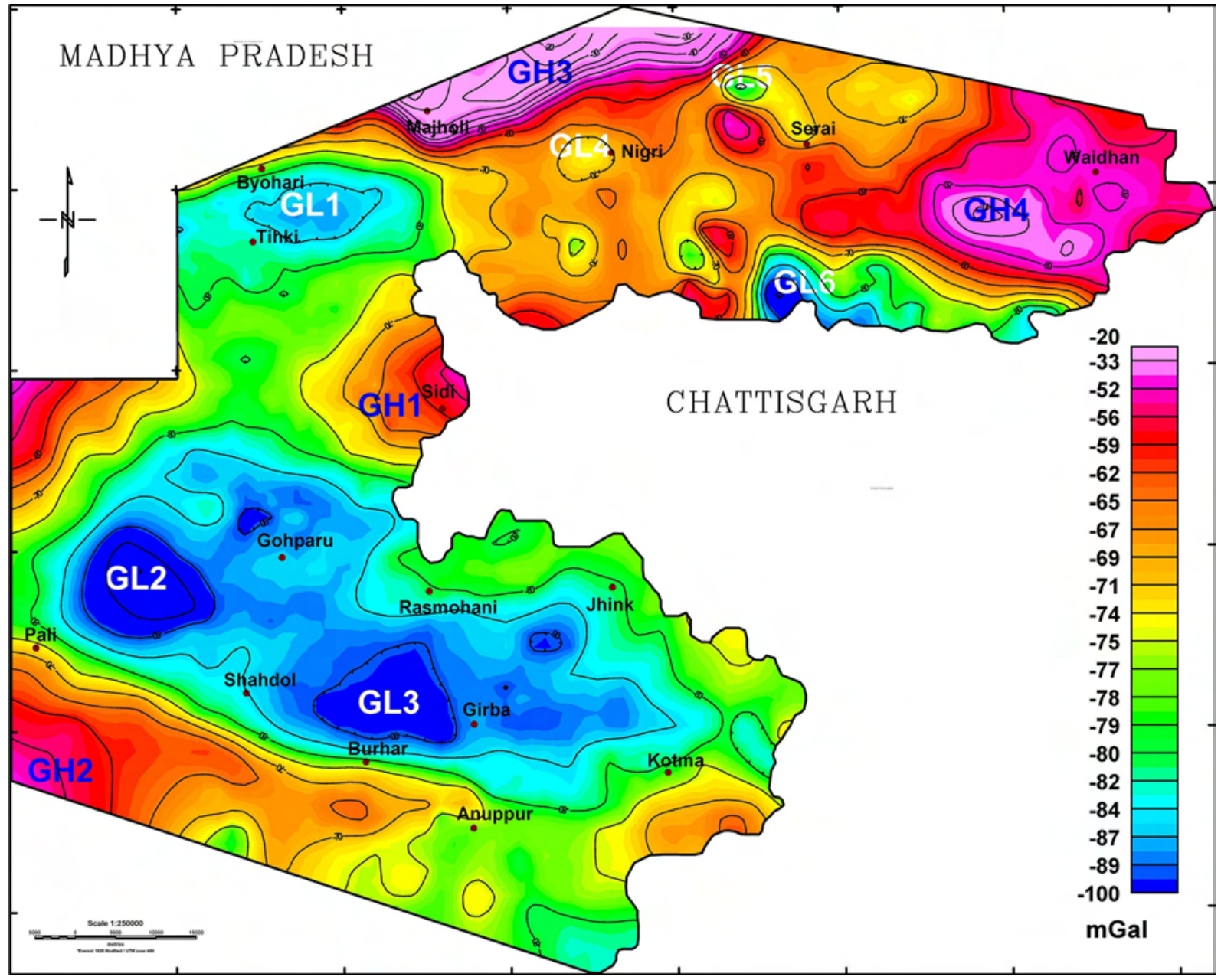

Figure 7. Bouguer anomaly map of the study area with marked Gravity Highs (GH1-GH4) in blue colour and Gravity lows (GL1-GL6) in white colour.

respectively were deployed. Gravity surveys began with establishment of network of gravity bases at permanent structures, which are tied to the existing gravity base at Bilaspur for which absolute gravity value is known (Qureshy et al. 1973). A correction of $15.0 \mathrm{mGal}$ was applied to this value to bring the data to international gravity standardization net (IGSN71). Precise determination of elevation and location of each gravity station was obtained through a precision topographical survey deploying Auto level instruments. The observed gravity reading at each station is corrected for (i) earth tidal effect, (ii) drift of the instruments, (iii) change in elevation (including free air, Bouguer and terrain effects) and (iv) latitudional variation. Bouguer and terrain correction was computed for the plate density of $2.67 \mathrm{~g} / \mathrm{cm}^{3}$. In view of the odd shape of the study area, additional gravity data from the surrounding area totalling 263 stations (NGRI database) were added to the newly acquired gravity database. Compatibility of the two datasets was checked along a profile and also at overlapping points before the finalization of the grids and maps. After applying these corrections to gravity readings, we created the Bouguer anomaly grid at $2 \mathrm{~km}$ grid interval for further analysis and interpretation. The present Bouguer gravity anomaly map of the South Rewa basin depicts anomaly pattern, which is similar to published NGRI-GSI gravity series map of India-2006. However, present gravity survey has brought out additional details as compared to NGRI-GSI gravity series map of India-2006 prepared from $5 \times 5 \mathrm{~km}$ gridded data acquired from sparse gravity observations at 2 to $10 \mathrm{~km}$ interval (NGRI-GSI map series-2006).

Bouguer anomaly map of the study area (figure 7) reveals total amplitudes of $80 \mathrm{mGal}$ varying between -100 and $-20 \mathrm{mGal}$. In general, the gravity field is higher in the north and NE part with a relative maximum of about $-20 \mathrm{mGal}$ near Majholi while the gravity field is predominantly low in the south. The map reveals two gravity lows GL1 
and GL2 which is separated by an E-W trending gravity high GH1 near Sidi. The gravity low GL1 is elongated in $\mathrm{E}-\mathrm{W}$ direction and is located to the north of Tihki well which encountered basement at a depth of $4.0 \mathrm{~km}$. This low is delimited on the north by the positive gravity anomalies having steep gravity gradient which suggests steep faulted basement exposed towards the north of the area (figure 7). The broad gravity low GL2 elongated in NW-SE direction suggests a major depression in the basement aligned in the direction of Mahanadi graben suggesting influence of Mahanadi tectonics over this region. The amplitude of this low is large compared to GL1; indicating that the basin must be deeper than the Tihki sub-basin in the north despite the fact that only the lower sequence of Gondwana sediments are present in the south compared to north where upper sequences are also present. Keeping this in view, it may be pointed out that part of the low encountered in the south could be due to deep seated source. The gravity low GL2 is divided into two parts by a NE-SW trending gravity high passing from Shahdol to Rasmohani. It is bordered by relative gravity high GH2 towards SW having sharp gravity gradient suggesting steep faulted basement. Gravity high GH2 is located over exposed high density Deccan volcanics resting over the basement. Apart from these significant highs and lows, other small amplitude gravity lows can also be seen in the NE part of the map (GL3, GL4 and GL5).

Another significant feature on the map is a large amplitude linear relative gravity high (GH3) in the northern part of the area. The sharp gravity gradient at its southern flank coincides with the known boundary fault between the exposed Archean basement/Mahakoshal rocks towards the north and the South Rewa Gondwana basin towards the south. Similarly, the large amplitude gravity high GH4 near Waidhan is conspicuous and may also represent high density Mahakoshal rocks over the Archean basement. Apart from these, small amplitudes and short wavelength anomalies in the northern and north eastern part of the area suggest shallow basement.

\subsection{Magnetic survey}

Magnetic survey was conducted using proton precession magnetometers having accuracy of $1 \mathrm{nT}$ with magnetic observations at each gravity stations. Apart from this additional magnetic observation was also recorded in between gravity stations in order to locate mafic dykes and sills and basaltic intrusions. This has resulted in a total of 6416 observations at $1 \mathrm{~km}$ interval along the roads and tracks. Observed magnetic readings were corrected for (i) diurnal variations of the earth's magnetic field and (ii) dipole nature of the earth's magnetic field known as geomagnetic reference field and finally the corrected total intensity magnetic anomaly digital grid is prepared at the same grid spacing of $2 \mathrm{~km}$ as adopted in the case of gravity gridding.

The IGRF (International Geomagnetic Reference Field) corrected magnetic anomaly map of the region (figure 8) shows anomaly variation of about $2365 \mathrm{nT}$ with a low of $-1369 \mathrm{nT}$ and high of 995 $\mathrm{nT}$. In general, the nature and texture of IGRF corrected magnetic anomalies are same as that observed in total intensity magnetic map except that the anomalies are sharper and well defined and show good correlation with exposed dykes and faults at number of places. In general, amplitudes of magnetic anomalies are positive in the north whereas anomalies are predominantly negative in the south except near Shahdol and south of Kotma where it shows positive anomalies. The nature of anomalies over the exposed basement/Mahakoshal metasediments near Majholi in the north is positive (MH1) suggesting that the basement rocks have large mafic content in them. The known boundary fault in the northern part revealed a sharp gradient of magnetic anomalies indicating steep normal fault in the basement. Some significant high-low pair of anomalies near Rasmohani (MH2ML2), Pali (MH3-ML3), Sidi (MH4-ML4) and Anuppur/Kotma (MH5-ML5) may be associated with basic intrusive dykes. It may be mentioned that an E-W striking vertical magnetic dyke at geomagnetic inclination of $30^{\circ} \mathrm{N}$ (study area latitude) will produce a predominant low to the north and a small high to the south if the magnetization is by induction alone. From the examination of these anomalies pair it is observed that they deviate from normal at number of locations that can be explained by incorporating remanent magnetization of the Deccan basalt.

\section{Analysis of $\mathrm{G}-\mathrm{M}$ data}

Analysis of G-M data usually means application of various analytical tools/techniques to understand the nature of causative sources that 


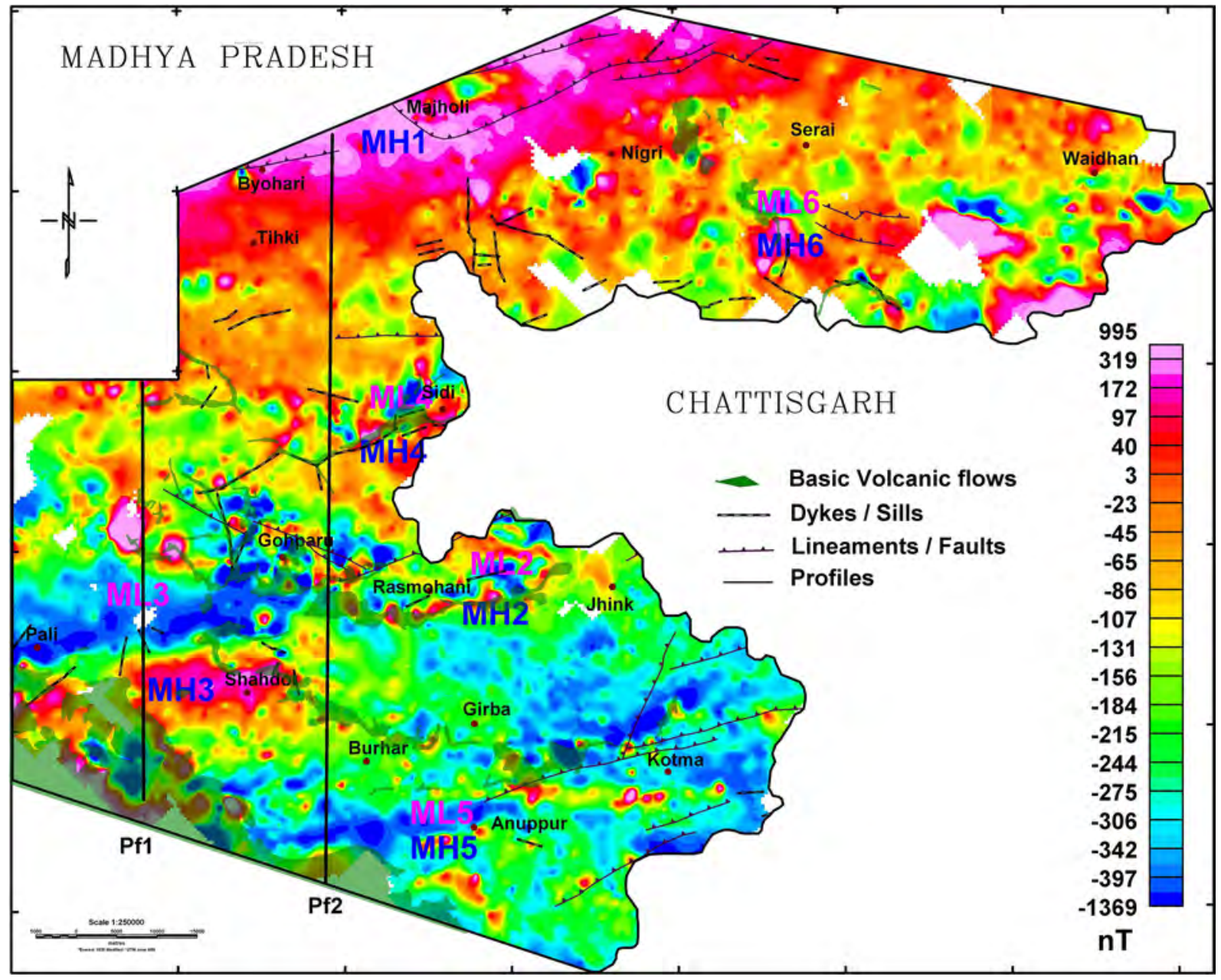

Figure 8. IGRF corrected total intensity magnetic anomaly map with marked magnetic high (MH) and magnetic low (ML) and some significant high-low pair of anomalies (MH1, MH2-ML2, MH3-ML3, MH4-ML4, MH5-ML5, MH6-ML6 along with Pf1 and Pf2 show profile locations adopted for joint G-M modelling.

produce the measured anomalies. Since the anomalies are cumulative effect of causative sources at various depths, the first task in G-M data analysis is to isolate the anomalies into its various components through the application of signal processing/enhancement techniques.

\subsection{Regional and residual separation of gravity data}

There are a number of methods for regionalresidual separation such as (i) graphical (ii) polynomial approximation (iii) finite element and (iv) frequency filtering which can be used for separation of effect due to various sources distributed at different depths. These methods are effective in certain geological situations and provide useful information but none of these provide unique solution. Regional and residual maps for the entire area based on polynomial, finite element and frequency domain filtering techniques are prepared for comparison. We observed that regional and residual maps obtained from finite element and frequency filtering techniques are very similar and we have adopted residual maps using frequency filtering for further analysis.

\subsubsection{Frequency domain filtering}

In the frequency domain filtering, depth to various causative sources can be estimated based on their frequency contents. In general, high frequency (short wavelength) anomalies are due to shallow sources, while low frequency (long wavelength) anomalies are due to sources at greater depth. The radially averaged power spectrum of the data shows a curve decaying with increasing frequency (Spector and Grant 1970). In this approach, depth to the 
statistical ensemble of sources is determined by the expression:

$$
h=-\frac{S}{4 \pi},
$$

where $h$ is the depth and $S$ is the slope of the $\log$ (power) spectrum. This means, power spectrum plotted on a semi-logarithmic scale would show linear segments. The slope of each segment provides the average depth estimate of the ensemble of sources lying at different depths. The cut-off frequencies corresponding to different linear segments on the frequency spectrum plot can be judiciously used in the filter operator to filter the different frequency contents present in the observed data leading to regional and residual maps.

The radial spectrum plot of the observed gravity field is shown in figure 9(a). It shows three linear segments corresponding to sources at depths of about 20, 4.3 and $2.6 \mathrm{~km}$ which suggest that the last two segments correspond to sources related to basement structures and the 1st segment corresponding to low wave number are caused due to sources in deeper crust. On the other hand, radial spectrum plot of the magnetic field (figure $9 \mathrm{~b}$ ) shows only shallow sources at a depth of about 4.7, 3.0 and $1.0 \mathrm{~km}$ which appears to be related to basement undulations and intrusive dykes and sills. In order to decompose the observed gravity fields into different component, frequency domain filters were applied corresponding to cutoff wave numbers as shown in the radial spectrum plot (figure 9a). Since, structural features and trends are very well reflected in residual anomaly map caused due to basement undulations and density heterogeneities within it, we obtained residual and regional anomaly maps through application of high pass and low pass filters.

\subsubsection{Regional and residual maps from frequency filtering}

Figure 10(a) shows the regional anomaly map of the study area derived from the low pass filter with a cutoff wavelength of $60 \mathrm{~km}$, which reveals a NW-SE trending predominant Gravity low due to deep seated source. Figure 10(b) shows the residual anomaly map obtained after high pass filter corresponding to cutoff wavelength of $60 \mathrm{~km}$. The residual anomaly map indicates a number of significant highs and lows with amplitudes ranging from -13 to $+14 \mathrm{mGal}$. It depicts an $\mathrm{E}-\mathrm{W}$ trending gravity low GL1 in the north near Tihki which is bounded by gravity high GH1 in the north and GH2 towards the south. The large amplitude gravity high GH1 having sharp gradient at the northern boundary of the map suggests steep basement fault. It is interesting to note that the NW-SE trending prominent gravity low present in the southern part in BA map is quite subdued in the residual map pointing to the fact that it has a large regional component. It is separated into two lows one near Pali (GL2) and other near Burhar (GL3) by a prominent NE-SW trending gravity high due to basement up warp near Shahdol. Another important feature on the map is an E-W to WNW-ESE trending linear gravity high (GH3) in the southern most part of the study area which probably indicates very shallow basement or basic intrusive body at shallow depth. Yet another prominent gravity high GH4 south of Serai in the northeastern part probably represent basement ridge. Presence of gravity low below the exposed volcanic cover further south indicates occurrence of subtrappean sediments. Thus, the residual map has brought number of depressions and up-warps in the basement. Therefore, this map appears to be more realistic which correlates with the geology and tectonics more closely.

\subsection{Structural analysis}

In order to detect the structural elements present in the gravity and magnetic maps, gradient analysis has been performed for magnetic and gravity data. Horizontal gradient maps are vivid, simple and intuitive which reveal the anomaly texture and highlight anomaly-pattern discontinuities. Computation of horizontal gradients is an extremely useful method in delineating the boundaries of source rock (Cordell and Grauch 1985; Blakely and Simpson 1986). The steepest horizontal gradient of a gravity anomaly will be located directly over the edge of the body if the edge is vertical and far removed from all other edges or sources. The horizontal gradient is simply a measure of the lateral change in density or magnetization of upper crustal rocks. Its magnitude is dependent on the density contrast across the boundary, the vertical extent of the contrast, the dip of the boundary and its depth of burial. The analysis requires no assumptions about the sources.

Since the gradient transforms are non-linear, their order in relation to other processing steps 

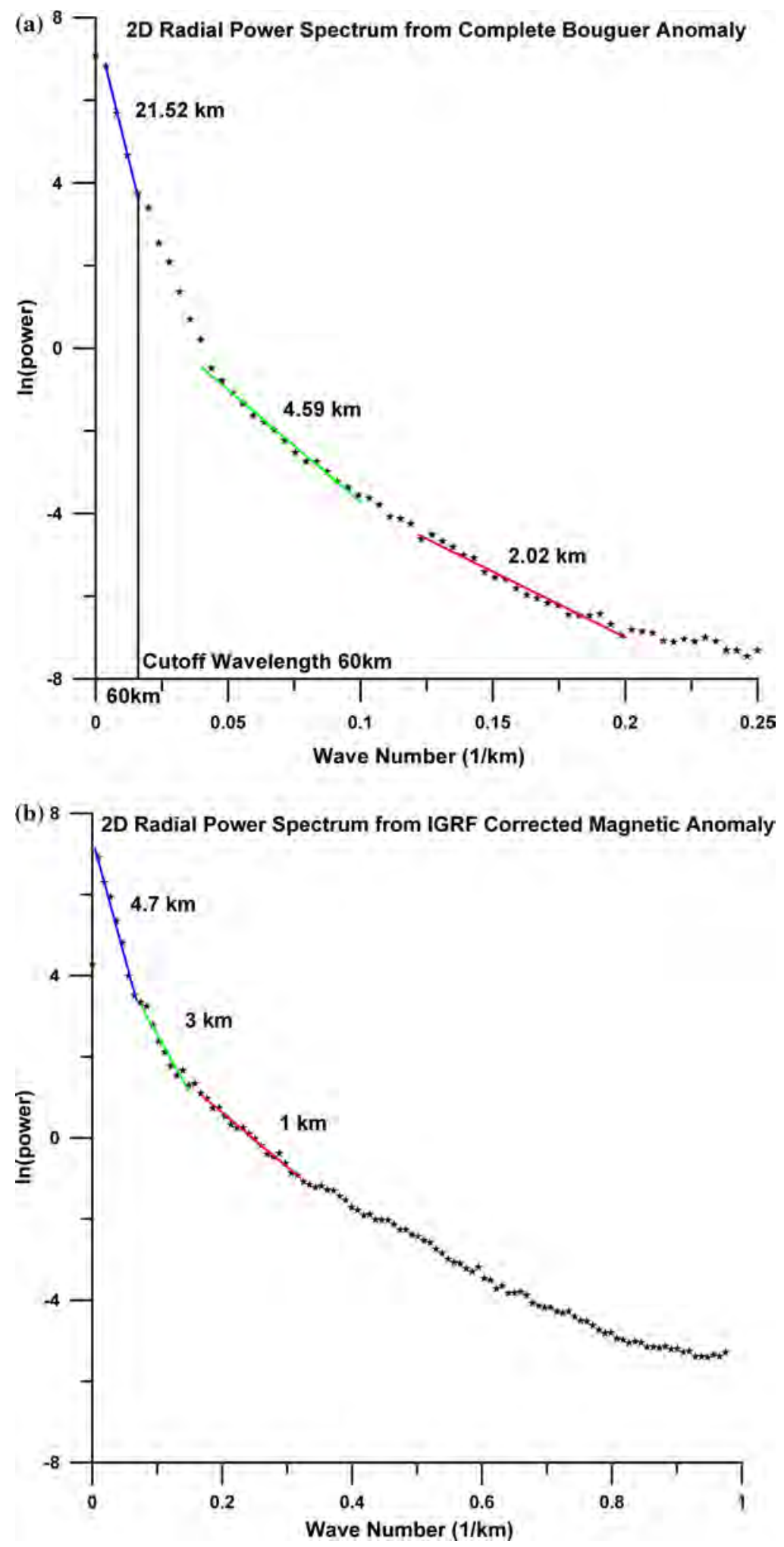

Figure 9. (a) Radially averaged power spectrum of the complete Bouguer anomalies of the study area shows three segments corresponding to sources at depths of about 21.52, 4.59 and $2.02 \mathrm{~km}$ which suggest that the last two segments correspond to sources related to basement structures and the 1st segment corresponding to low wave number are caused due to sources in deeper crust. (b) Radially averaged power spectrum plot of the IGRF corrected total intensity magnetic anomalies shows only shallow sources at a depth of about $4.7,3.0$ and $1.0 \mathrm{~km}$ which appears to be related to basement undulations and intrusive dykes and sills. 
(a)

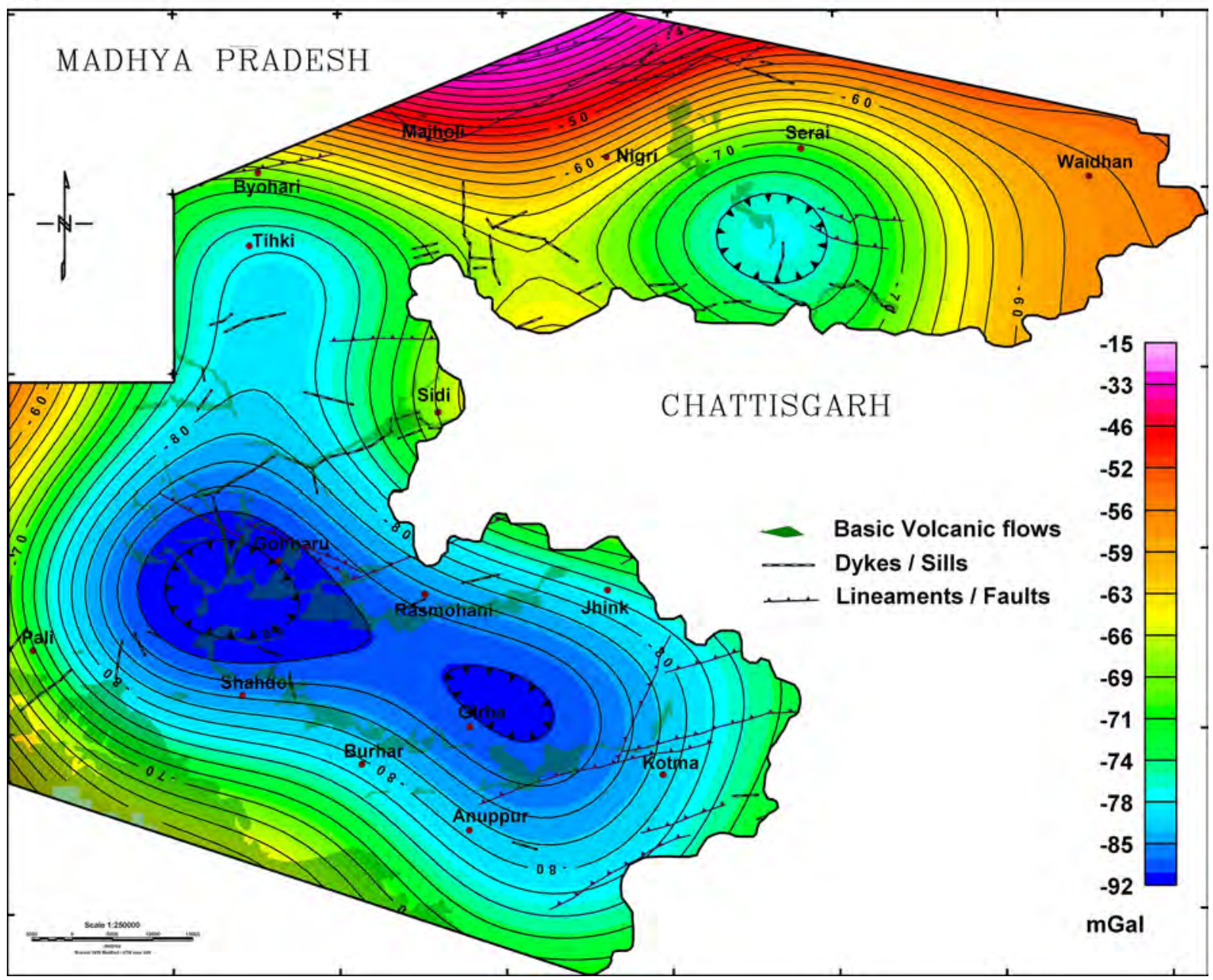

Figure 10. (a) Regional gravity anomaly map derived from low pass filter with cutoff wavelength at $60 \mathrm{~km}$. (b) Residual gravity anomaly map derived from high pass filter with cutoff wavelength at $60 \mathrm{~km}$ with marked gravity highs (GH1-GH4) in blue colour and gravity lows (GL1-GL3) in white colour along with Pf1 and Pf2 show profile locations adopted for joint G-M modelling.

such as frequency filtering will affect the result. The horizontal gradient $H(F)$ of an anomaly field $F$ is calculated as the Pythagorean sum of the gradients in the orthogonal directions. Choosing the directions to be along the ones of the grids, the calculation becomes:

$$
\left(G y z^{2}+G x z^{2}\right)^{1 / 2}=H(F) .
$$

Thus, this is the absolute value of the horizontal gradient at $x, y$, i.e., the value of the horizontal gradient in the direction of greatest increase. The ridges of maxima on the horizontal gradient of Bouguer gravity are recognized generally as being good locators of edges of shallow vertical/near vertical body.

\subsubsection{Horizontal gradient of bouguer and magnetic anomaly maps}

Figure 11 shows the horizontal gradient map of gravity data of the South Rewa basin. The most significant features on the map are: (i) ENEWSW trending gradient maxima in the north near Majholi (HZ1) which coincides with the lineament representing boundary fault between basement in the north and Gondwana rocks towards south, (ii) NW-SE to WNW-ESE trending gradient gravity maximum near Burhar and Anuppur (HZ2) represents faulted basin boundary (iii) ENE-WSW trending gradient maximum near Rasmohani (HZ3), (iv) HZ4 represents the boundary of the basement ridge inferred in the Residual map, (v) ENE-WSW trending gradient maxima (HZ5) 
(b)

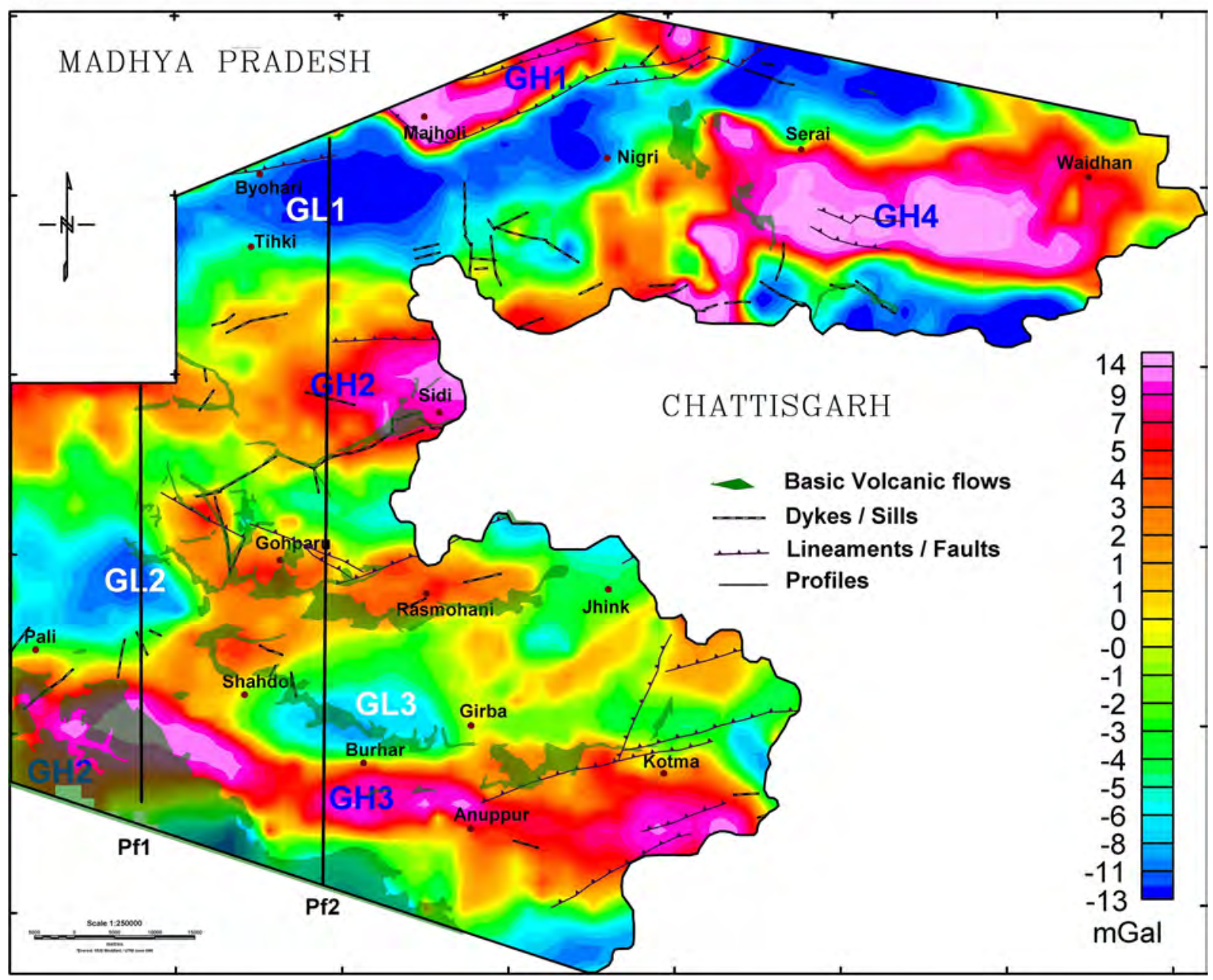

Figure 10. (Continued.)

north of Shahdol represents the boundary of the basement upwarp. It appears to be related to basement up-warp separating two basins.

Computation of horizontal gradient of total intensity magnetic data requires transformation of observed magnetic grid to reduce to pole (RTP) grid. RTP technique transforms induced magnetic responses of dipolar nature at mid to low latitudes to those of simpler symmetric response that would arise were the sources placed at the magnetic pole (vertical field). This simplifies the interpretation because for sub-vertical prisms or sub-vertical contacts (including faults), it transforms their asymmetric responses to simpler symmetric and anti-symmetric forms. The symmetric 'highs' are directly centred on the body, while the maximum gradient of the anti-symmetric dipolar anomalies coincides exactly with the body edge. The horizontal gradient method is relatively insensitive to the ambient noise in the data and to the interference effects between the nearby sources. It is complimentary to the filtered and vertical derivatives enhancement maps and produces more exact location of faults than the first vertical derivatives. The vertical derivative technique serves much the same purpose as the residual filtering in gravity and magnetic maps. It emphasizes the expression of local features and removes the effects of regional anomalies (Blakely 1995).

Figure 12 shows the horizontal gradient map of magnetic data of the South Rewa basin. The most prominent trend is ENE-WSW direction which coincides with the orientation of the dykes and other significant trend is WNW-ESE which coincides with the boundary faults of the basin.

The most coincident features on the gradient maps of the magnetic and gravity data are (i) ENE-WSW trending magnetic and gravity 


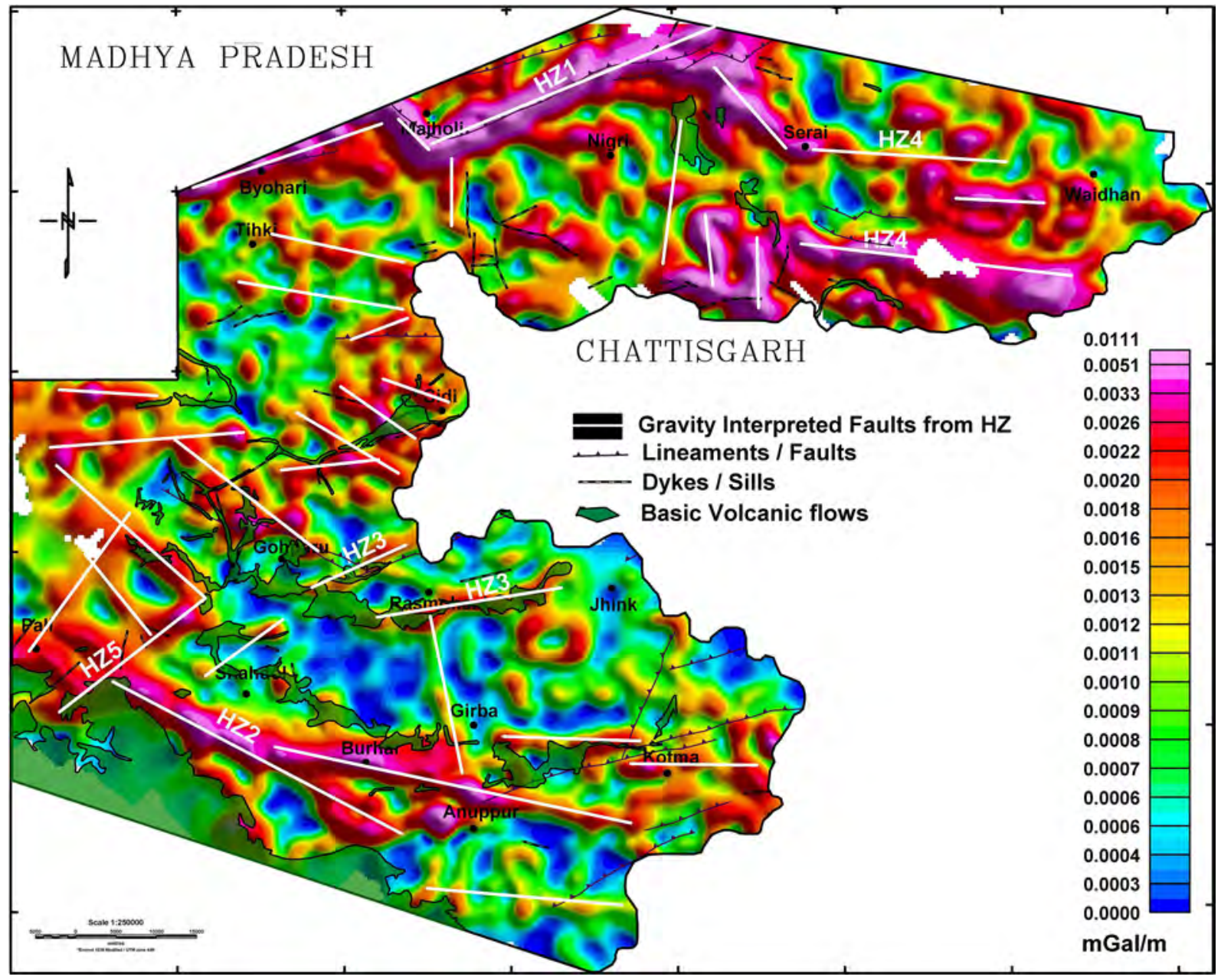

Figure 11. Horizontal gradient (HZ) map of Bouguer anomaly with marked gradient maxima (HZ1-HZ5) shows the gravity interpreted faults in white colour.

maxima in the north near Majholi (ii) NW-SE to WNW-ESE trending gradient maxima near Anuppur and Kotma (iii) ENE-WSW trending gradient maxima near Rasmohani which suggests that causative sources are same in gravity and magnetic data.

\subsubsection{Tilt derivative (TDR) technique}

The TDR method, also called tilt angle method, is a refinement of the analytic signal method suggested by Miller and Singh (1994) and by Verduzco et al. (2004). The TDR determines the location and depth of vertical magnetic contacts without prior information on the source configuration by using the horizontal gradient amplitude of the tilt angle. The method has been further developed by Salem et al. (2007, 2008) and Fairhead et al. (2008). The TDR method was used to enhance and sharpen the potential field anomalies (Verduzco et al. 2004;
Cooper and Cowan 2006). The advantage of TDR is that it shows zero contour line located on or close to the contacts. The TDR is defined as:

$$
T D R=\tan ^{-1}\left(\frac{\partial F / \partial z}{\sqrt{\left((\partial F / \partial x)^{2}+(\partial F / \partial y)^{2}\right)}}\right)
$$

where $F$ is the magnetic field observed at $(x, y)$, and $(\partial F / \partial x, \partial F / \partial y$, and $\partial F / \partial z)$ are the two horizontal and vertical derivatives of the magnetic field, respectively. The TDR method has the advantage of responding well to both shallow and deep sources, and the map of TDR recognizes the horizontal location and extent of sources. The TDR of magnetic data are presented in figure 13. The zero contour line which reflects the contacts are predominantly aligned in ENE-WSW and 


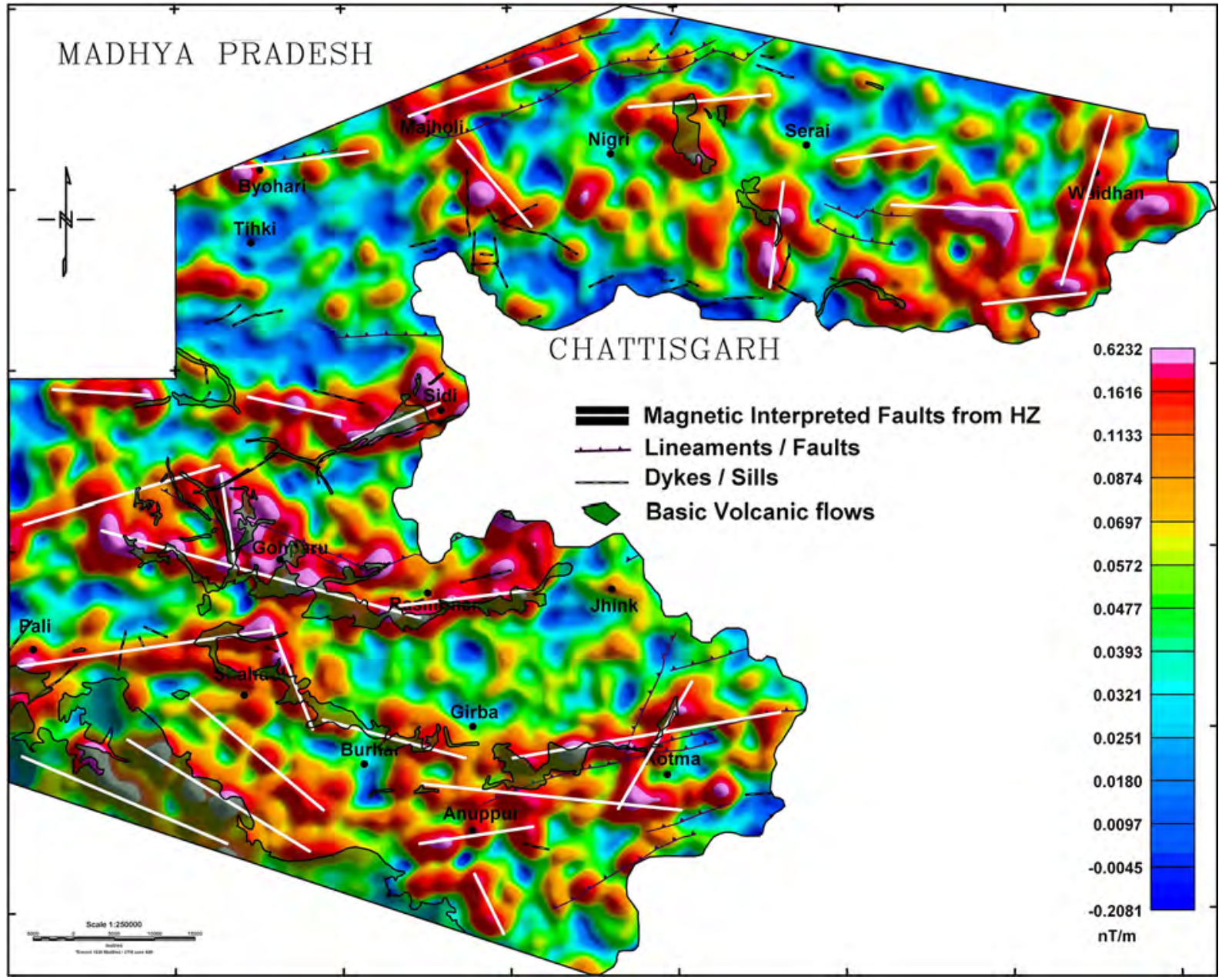

Figure 12. Horizontal gradient (HZ) map of magnetic anomaly with marked gradient maxima shows the magnetic interpreted faults/dykes in white colour.

WNW-ESE directions and also coincides with the horizontal gradient maximas at number of places.

\subsubsection{Euler 3D for direct determination of depth}

Euler's 3D is most widely used for direct detection of source depth while $2 \mathrm{D}$ and $3 \mathrm{D}$ modelling belongs to indirect category and is routinely used in $\mathrm{G}-\mathrm{M}$ interpretation.

Euler's homogeneity relation given as:

$$
\begin{aligned}
& \left(x-x_{0}\right) \frac{d T}{d x}+\left(y-y_{0}\right) \frac{d T}{d y}+\left(z-z_{0}\right) \frac{d T}{d z} \\
& =N(B-T)
\end{aligned}
$$

relates the fields and its gradient components to the location of source with degree of homogeneity $N$ (Thompson 1982), where $\left(x_{0}, y_{0}, z_{0}\right)$ is the position of a magnetic source whose total field $T$ is detected at $(x, y, z)$. The total field has a regional value of $B$. The degree of homogeneity $N$ may be interpreted as a structural index (SI) which is a measure of the rate of change with distance of a field. For example, in magnetic field narrow dyke has $\mathrm{SI}=1$ while vertical pipe gives $\mathrm{SI}=2$. In gravity, pipe has $\mathrm{SI}=1$ while sphere has $\mathrm{SI}=2$. Given a set of observation points, we can generate data grid which can be used to determine the optimum source location by solving Euler's equation for a given SI by least square inversion procedure. This inversion process is called Euler's deconvolution and provides quick results for source position and depth directly. We have used the Oasis Montaj gravity/magnetic interpretation software (Geosoft) to automatically locate and determine depth through Euler's 3D deconvolution software. We have used the magnetic grid and computed the Euler's depth for SI = 1 and the results are shown in figure 14. It is observed that the source depth derived for dyke model $(\mathrm{SI}=1)$ shows predominantly E-W and NW-SE trends and some of them coincides with the exposed dykes near Rasmohani, Sidi, Pali and Anuppur. The presence 


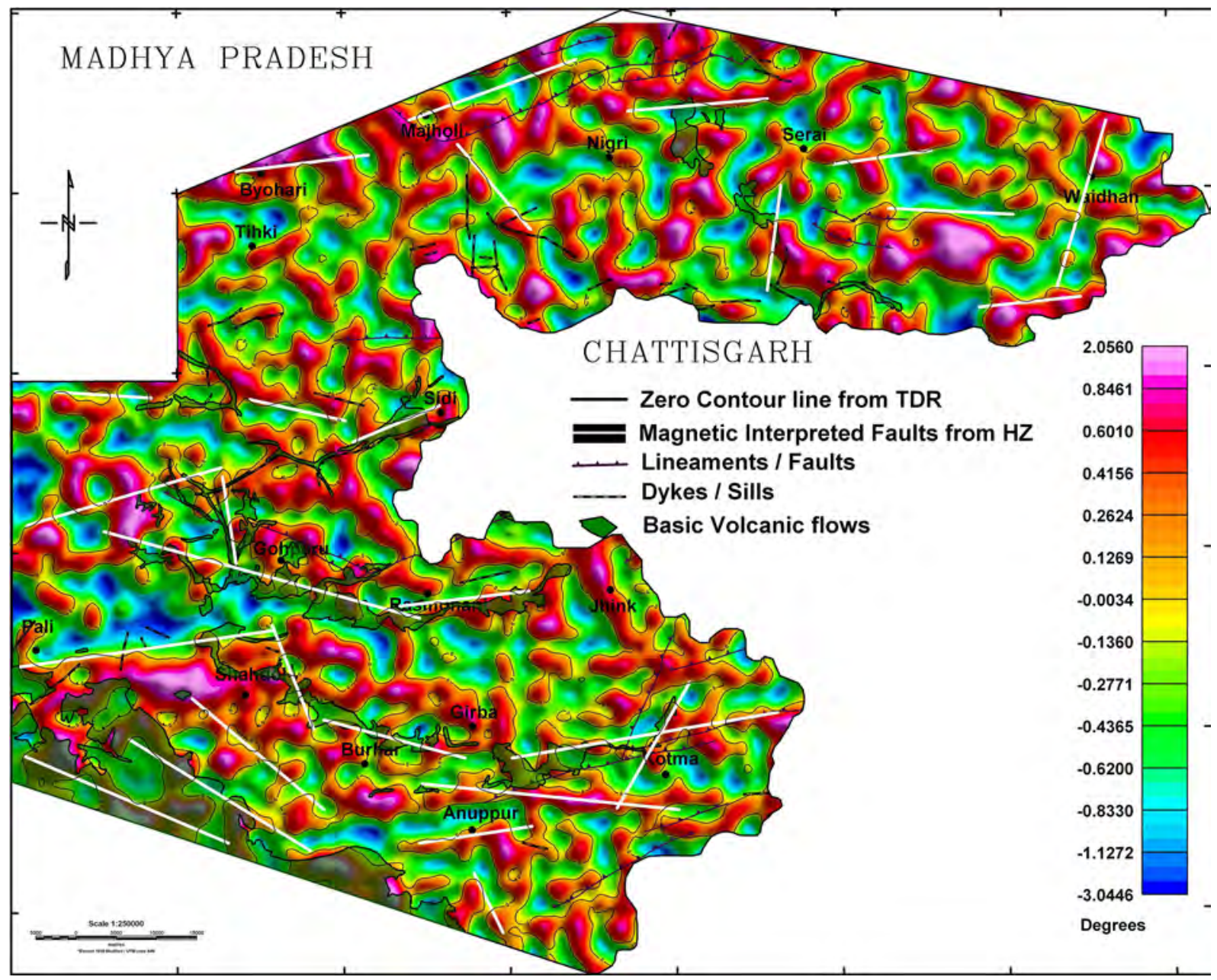

Figure 13. Tilt derivative map of magnetic anomaly with marked magnetic interpreted faults/dykes in dashed block colour and superimposed magnetic interpreted faults/dykes from horizontal gradient method in white colour and solid black colour shows the zero contour line.

of large source depth towards the NE of Tihki and also towards the north of Shahdol is conspicuous and may be caused due to basic intrusive emplaced along the faulted basement/ridge. In general, the magnetic source depth distribution map shows mixed distribution of source depths suggesting that magnetic anomalies are cumulative effect due to magnetic basement at depth and shallow dykes. However, some pattern can be seen. For example, sources near Rasmohani, Gohparu and south of Girba are mostly shallow whereas sources north of Shahdol and SE of Byohari are deeper in general.

\subsubsection{Basement relief map from inversion of gravity}

Based on the Harmonic inversion (Mishra and Pederson 1982) of residual gravity anomalies, independent information regarding the depth of causative source can be obtained. This method works in frequency domain and assumes that the body has uniform density contrast and a flat bottom and anomalies are caused due to variation in the depth to the upper surface representing the basement relief. In this method, the Fourier transform of the gravity field is expressed as the Fourier transform of the basement relief multiplied by a suitable filter function.

$$
g(f)=\left[2 G \rho \exp \left(-\frac{2 f z_{0}}{\lambda}\right)\right] z(f)
$$

where $g(f)$ is the transforms of the observed gravity fields, $f$ is the spatial frequency, $z(f)$ is the fourier transform of the basement relief over the average depth $z_{o}, \rho$ is the density contrast across the basement relief and $\lambda$ is the wavelength equal 


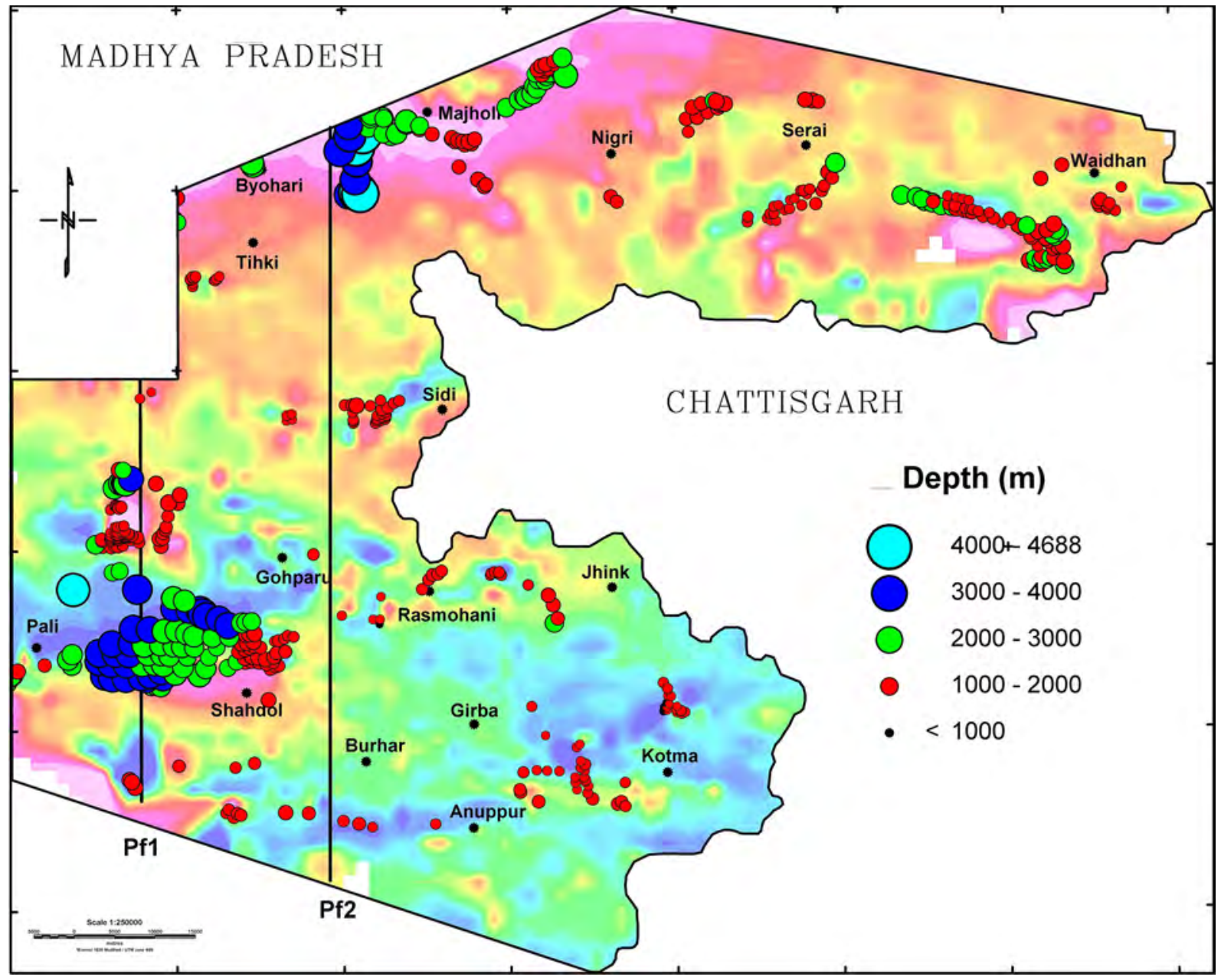

Figure 14. Magnetic source depth derived from Euler' 3D method for dyke model (SI=1) along with Pf1 and Pf2 show profile locations adopted for joint G-M modelling.

to the length of the profile or the block size being analyzed.

The free parameters $\rho$ and $z_{o}$ in this equation characterize the non-uniqueness of this inversion scheme. The solution for $z$ depends on the value selected for these parameters.

The above equation can be treated as a linear system with transforms of the field as input and the transform of the relief as output with quantities in bracket on the right hand side as filter function. The inverse of this filter function multiplied by the transform of the observed gravity field provides the transform of the basement relief whose inverse transform is the basement relief itself.

To employ this technique, density contrast between the basement and the sedimentary column is taken as $0.25 \mathrm{~g} / \mathrm{cm}^{3}$ assuming that the average density for the sedimentary column is $2.45 \mathrm{~g} / \mathrm{cm}^{3}$ and density for the basement is $2.7 \mathrm{~g} / \mathrm{cm}^{3}$. Since the method is based on the inversion of gravity anomalies in terms of single interface, gravity high will result in basement high and gravity low corresponds to basement low.

As the gravity field is vertical in nature, most of the basement features are located directly below the residual gravity anomalies. Inversion of the residual anomalies shows number of localized basinlike features and basement highs. These surfaces cannot be taken as a true representation of the basement geometry but provides smooth and approximate depth to the basement and serve as a guide for detailed modelling. The maximum depth to the basement is $5.5 \mathrm{~km}$ towards the northeast of Tihki well (Bijendra Singh et al. 2009). The most significant feature of the basement configuration map (figure 15) is a linear ENE-WSW trending basement depression in the north which is separated into three sub-basins (BL1, BL2, BL3) 


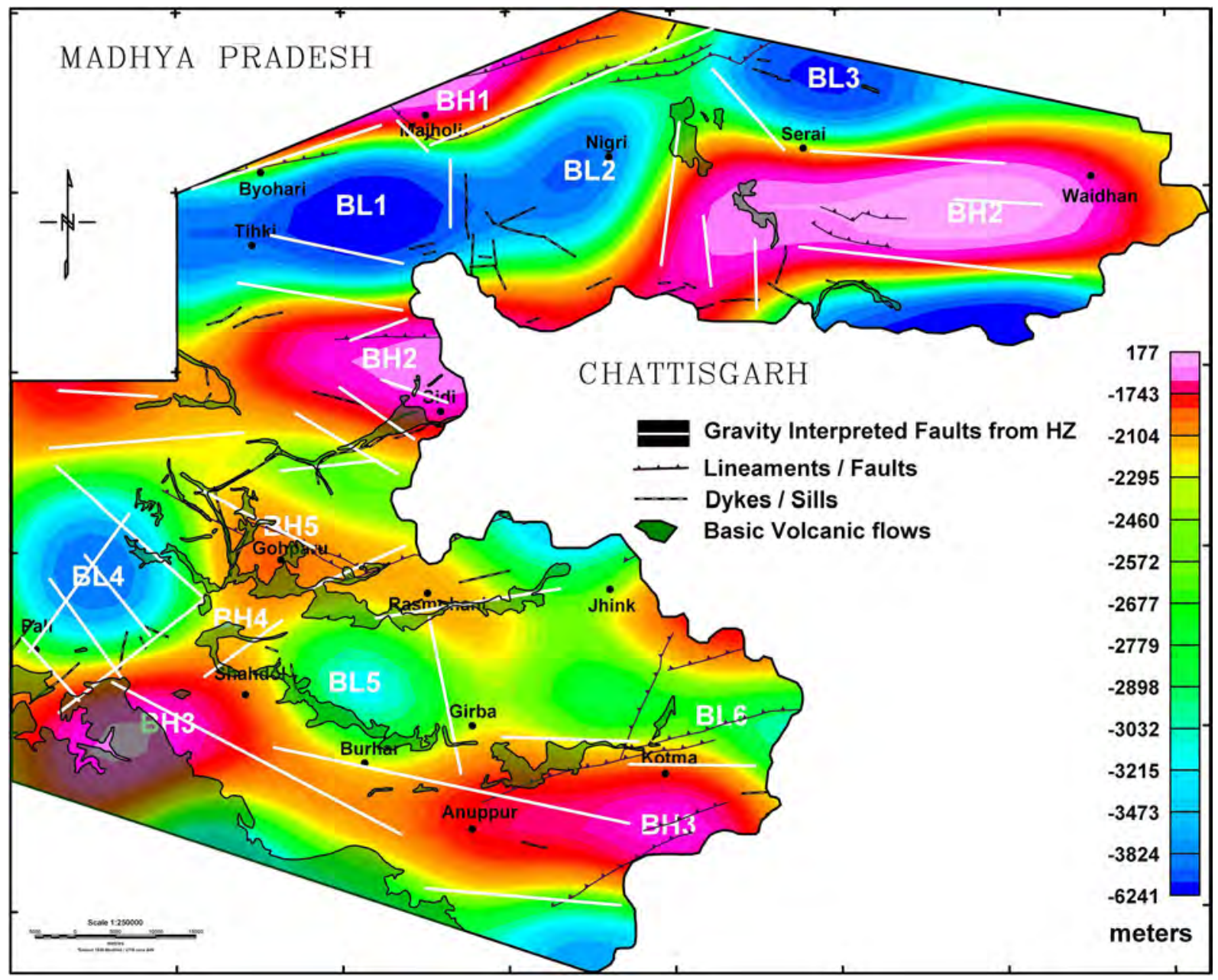

Figure 15. Basement configuration map derived from inversion of gravity data with marked basement highs (BH1-BH5) and basement lows (BL1-BL6) in white colour also shows the Basement faults in dashed block colour superimposed the gravity interpreted faults in white colour.

by the transverse basement ridges. It is delimited by the shallow basement in the north (BH1) and basement up warp/ridge in the south (BH2). Other prominent features on the map are (i) the NWSE trending basement depression in the south is divided into sub-basins (BL4, BL5, BL6) by the transverse ridges near Shahdol and Anuppur (ii) nearly WNW-ESE trending basement low in the southern most part of the study area below the Deccan volcanic suggests the presence of subtrappean sediments (iii) The WNW-ESE trending basement ridge $(\mathrm{BH} 3, \mathrm{BH} 4)$ in the south. It may be mentioned that the basement depths derived towards south of Gohparu may be under-estimated as the younger rock formation are conspicuously missing beyond this region resulting into reduction of average density contrast adopted between sedimentary and basement rocks.

\subsubsection{Two-and-a-half dimensional $G-M$ modelling}

Since the subsurface model derived from gravity and magnetic modelling independently is not unique, the uncertainty in the model is minimised by joint modelling of G-M anomalies. Further, constraints from seismic, Euler's depth and borehole information are incorporated in the model to arrive at a more plausible geological section.

Two profiles were selected (Pf1 and Pf2, figure 8) to carry out joint interactive $\mathrm{G}-\mathrm{M}$ modelling of residual gravity and IGRF corrected total intensity magnetic data. Average density values are ascribed to the different layers on the basis of density log of the Tihki well (Jitendra Kumar et al. 2005). Sediments are assumed to non-magnetic; hence the source depths derived from Euler's solutions of magnetic data provide constraints on position 
Table 1. Density and Magnetic susceptibilities of rock units.

\begin{tabular}{llcc}
\hline Sl. no & Litho-unit & $\begin{array}{c}\text { Density } \\
\left(\mathrm{gm} / \mathrm{cm}^{3}\right)\end{array}$ & $\begin{array}{c}\text { Susceptibility } \\
(\mathrm{CGS}) \times 10^{6}\end{array}$ \\
\hline 1 & Pali/Tihki & 2.37 & - \\
2 & Raniganj & 2.45 & - \\
3 & Barakar & $2.51-2.53$ & - \\
4 & Talchir & $2.54-2.55$ & $0.0001-0.0005$ \\
5 & Basement & 2.70 & $0.0011-0.0055$ \\
6 & Trap/volcanics & 2.74 & \\
\hline
\end{tabular}

of the intrusive dykes linked to short wavelength magnetic anomalies. Thus, the model is expected to reveal the major trends of the basement from the residual gravity data and delineate the basic intrusive dykes on the basis of the magnetic data. While modelling the magnetic anomalies, magnetic properties of dykes and sills were assigned based on palaeomagnetic measurements of the rock samples collected in the field. Palaeomagnetic measurements indicate that the exposed dykes belong to Deccan origin having direction of remanent magnetization ranging from (inclination) $I=-30^{\circ}$ to $-50^{\circ}$ and (declination) $D=310^{\circ}$ to $350^{\circ}$ and intensity of magnetization as 1.0 to 7.0 $\mathrm{A} / \mathrm{m}$ which belongs to normal polarity of Deccan magnetostratigrahy.

We have adopted 2.5-dimensional modelling approach keeping in view the limited dimension of the anomalies across the strike of the profile. Modelling is performed interactively using the GMSYS professional software. The software calculates the gravity and magnetic response from the initial model and provides an easy to use interface for interactively creating and manipulating the model to fit the observed and calculated gravity-magnetic anomalies. In general, four layers of non-magnetic sediments overlie the magnetic basement. Average density and susceptibility of various layers adopted are given in table 1.

Profile 1: The N-S trending profile located in the Western part of the study area traverses mainly Deccan volcanic, Pali and small patch of Lameta and Ranigunj exposures. It shows a prominent gravity and magnetic low at the centre of the profile flanked by highs on either side suggesting that they are caused due to variation in the basement geometry. The joint modelling of $\mathrm{G}-\mathrm{M}$ anomalies reveals the basement depression in the centre with shallow basement on either side. The sharp gradient in $\mathrm{G}-\mathrm{M}$ anomalies in the south is attributed to a steep faulted basement at the southern end. The basement is as shallow as $1 \mathrm{~km}$ in the south and is $5 \mathrm{~km}$ deep in the centre of the basin (figure 16a). The gravity low below the exposed Deccan volcanic in the south has been interpreted due to presence of subtrappean Gondwana sediments. The inferred geometry of the basement reveals a half graben with steep fault as its southern margin. The regional trend of $\mathrm{G}-\mathrm{M}$ anomalies resembles the basement topography. The short wavelength magnetic anomalies have been interpreted due to presence of volcanic sills and dykes of Deccan basalt having magnetization direction corresponding to upper normal $(29 \mathrm{~N})$ polarity chron.

Profile 2: This N-S profile passes through Tihki well in the north, which provided the constraints for the G-M modelling. The northern part of the profile shows sharp gravity low which is modeled due to abrupt depression in the basement having sediment thickness as high as $5 \mathrm{~km}$ (figure 16b). The interpreted section shows basement up-warp to the south of Tihki well which is caused due to a transverse basement ridge in this region. The ridge appears to divide the south Rewa basin into the northern and southern sub-basins. It may be noticed that inspite of relatively small order of the gravity low over the south sub-basin; the interpreted basement depth is of the same order as in the north due to the fact that only lower Gondwana sediments are exposed in this section. The gravity high towards the southern end is attributed to a steep basement up-warp. Decrease in gravity anomalies further south over the exposed Deccan volcanic is attributed due to sediments below the trap. The short wavelength magnetic anomalies have delineated number of volcanic intrusive some of which coincides with the exposed trap along this profile. The interpreted section shows a high density large mafic intrusive body of reverse magnetization (29R) near the basin boundary faults. Interpreted section reveals magnetization direction corresponding to upper normal $(29 \mathrm{~N})$ and reverse 
(a)

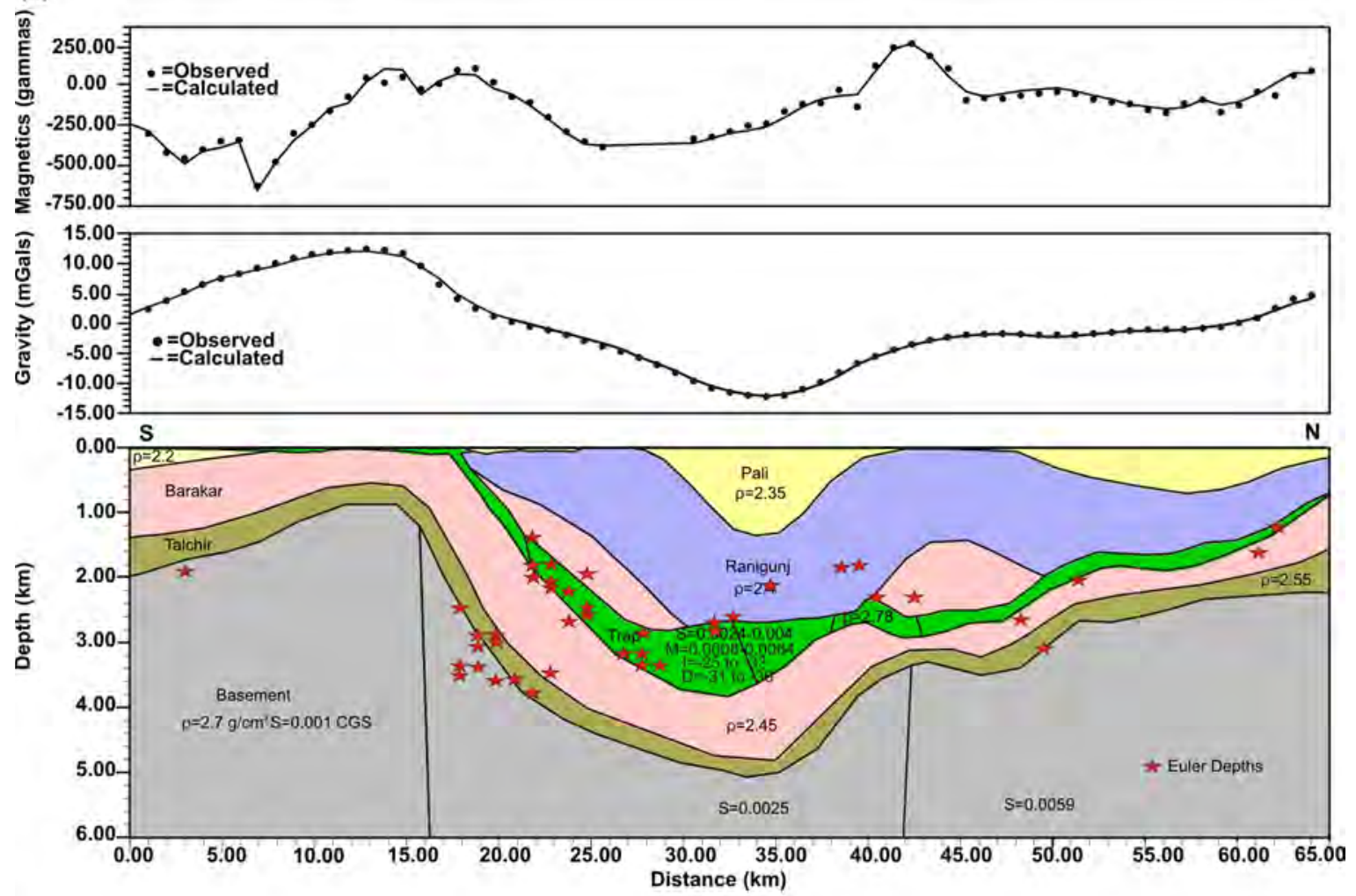

(b)
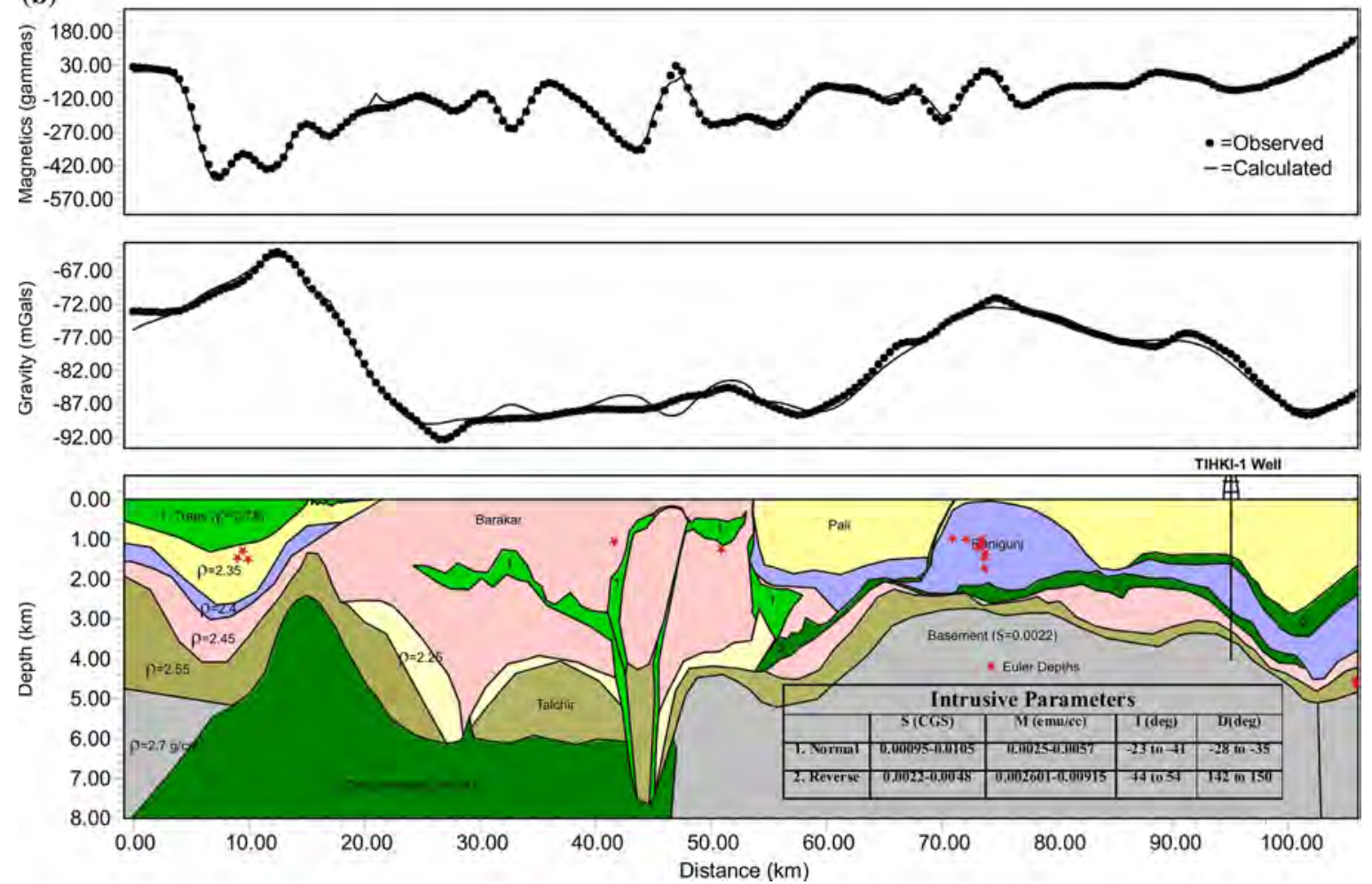

Figure 16. 2.5D joint modelling of G-M anomalies along (a) Pf1 and (b) Pf2. Density ( $\rho$ ), susceptibility $(S)$ and magnetization $(M)$ are given in CGS units, i.e., $\mathrm{g} / \mathrm{cm}^{3}$ and $\mathrm{emu} / \mathrm{cm}^{3}$, respectively. To convert CGS unit to SI unit, multiply density by $10^{3}$, susceptibility by $4 * \pi$ and magnetization by $10^{3}$ which are referred as $\mathrm{kg} / \mathrm{m}^{3}$, SI unit and A/m respectively and inclination $(I)$ and declination $(D)$ in degrees. Red stars in the depth section indicate Euler depths from magnetic data. 
(29R) of the Deccan magnetostratigraphy. This indicates that Deccan magma was emplaced during the main phase (29R) as well as late phase $(29 \mathrm{~N})$ events.

In general, the model reveals undulating basement topography with number of upwarps and depressions which are quite steep at few locations suggesting faulted basement/contact. The short wavelength magnetic anomalies are attributed largely to the shallow/exposed volcanic dykes where as large wavelength magnetic anomalies are interpreted due to basement topography or large mafic intrusive (magma chambers).

\section{Data integration with GIS}

Geospatial analysis is much easier when done in a GIS environment but geophysical processing software usually lacks GIS functionality. In GIS analysis, geophysical images are treated as a type of evidence map, same as other thematic maps such as topography, geologic, and structure maps. We transform the geophysical images to the GIS format by exporting the images into a GeoTIFF format. The GIS-based software such as ArcGIS10 integrates the raster and vector results extracted from geophysical data analysis. The integrated analysis of the different data types was applied to find the mutual relationship as a base for geological analysis. The ultimate application of this technique should result in a more detailed and accurate geological interpretation. In particular, the integration of such data provides new opportunities for studying the tectonic evolution of the study area.

Figure 17 shows the results obtained from the interpretation of potential field and RS data. The Rose diagram depicts predominantly three sets of ENE-WSW, W-E and WNW-ESE trending structural trends. The gravity and magnetic anomalies reveals largely ENE-WSW and W-E trending lineaments which are mainly associated with mafic dykes/sills which, appears to reflect the orientations of basaltic dyke swarms of the Deccan trap in Narmada-Tapti tectonic zone (Wei et al. 2013). While, WNW-ESE lineaments/faults derived from analysis of gravity and magnetic trends reflect basement faults associated with rifting event of the Mahanadi rift. The structural trends inferred from $\mathrm{RS}$ and geological studies predominantly reflect ENE-WSW trend, which coincides with orientation of ENE-WSW trending Son-Narmada lineament. Remote sensing data depicts 133 lineaments in ENE-WSW direction.
Gravity data have revealed 36 subsurface faults oriented in WNW-ESE direction, which are not exposed on the surface. While, magnetic data have brought out 56 shallow dykes/faults aligned in ENE-WSW direction, which coincides with the surface lineaments of Remote sensing data. The lineaments inferred from horizontal gradient of gravity and magnetic data coincides at number of places such as near Majholi, Anuppur and Rasmohani. These lineaments have no surface evidence hence could not be discovered by remote sensing and geological mapping. It is observed that a total of 49 geologically mapped faults and 43 dykes mapped on the surface shows ENE-WSW direction, which coincides with those, inferred from RS and magnetic data. The rose diagrams clearly indicate that the lineaments inferred from RS, geological and magnetic data are aligned in ENE-WSW direction whereas the basement faults inferred from gravity are aligned in WNW-ESE in the northern part and NW-SW in the southern part of the basin. It probably suggests two independent tectonic events (i) NW-SE to WNW-ESE associated with the extension/development of the rift and (ii) ENEWSW associated with the reactivation of ENEWSW trending preexisting Son-Narmada faults during Deccan volcanism and facilitated emplacement of magma in the form of dykes.

\section{Discussions}

Integration of remote sensing, geological and $\mathrm{G}-\mathrm{M}$ studies is expected to provide details of subsurface structural features apart from disposition of dykes and sills and the basement configuration of the basin. Analysis of gravity data has clearly brought out boundary faults and basement ridges, which are orthogonal. Observed gravity low over the exposed Deccan volcanics in the south is an anomalous feature and probably indicates presence of Gondwana sediments below the Deccan basalts. Lack of significant magnetic anomalies below the exposed basalts towards the south also suggests the absence of mafic intrusive. The inferred regional gravity low is a part of large wavelength gravity low observed over the Son-Mahanadi basin and apparently has deeper origin. Interestingly, regional gravity low bears an inverse correlation with regional high topography, which suggests that the excess topographic load at the surface is isostatically compensated due to buoyancy caused by upwarp of the lower density asthenosphere formed by impact of the Deccan magmatism 


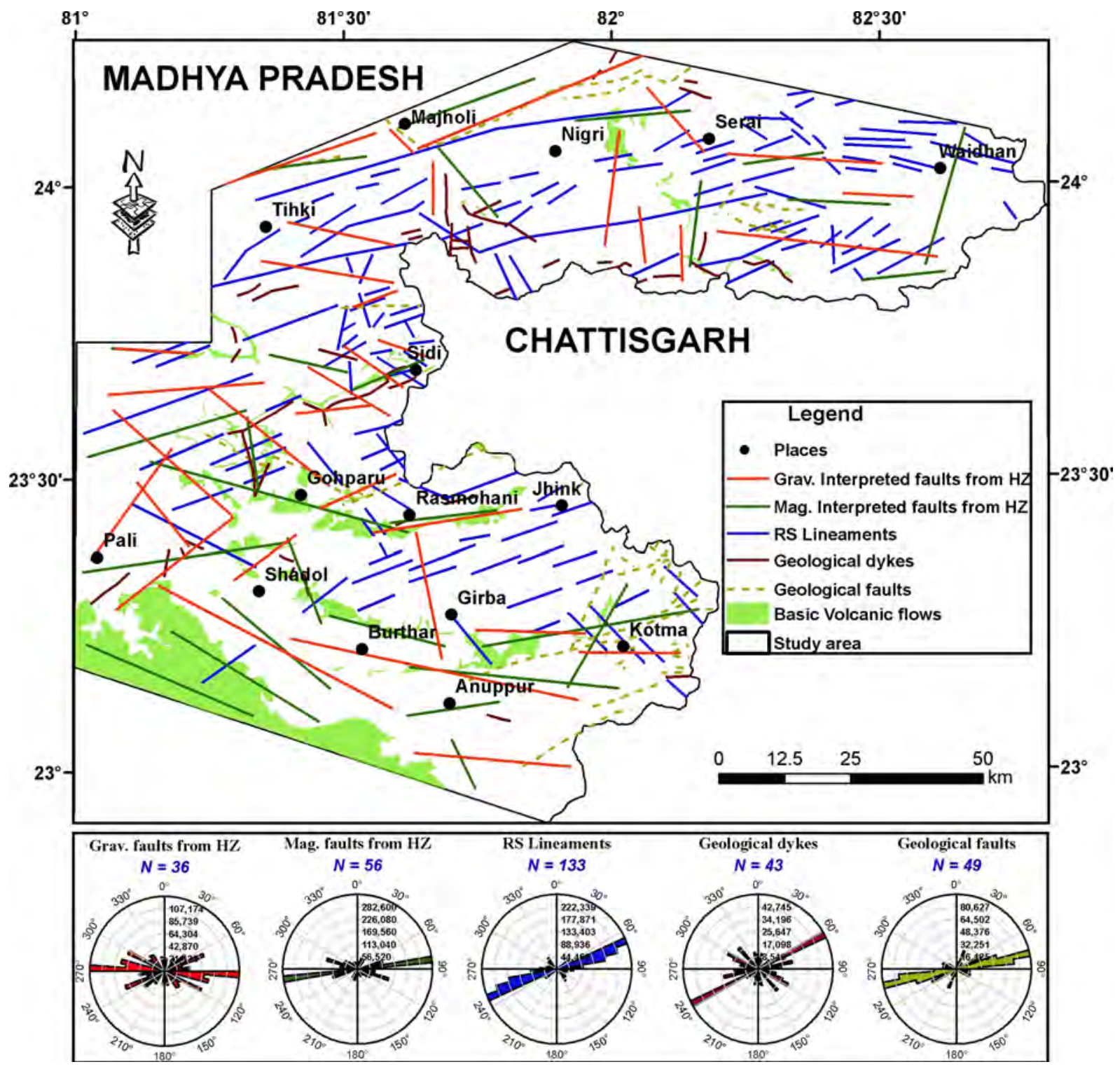

Figure 17. GIS integration map of surface and subsurface structures with rose diagrams. In the figure, Grav: gravity, mag: magnetic, RS: remote sensing, HZ: horizontal gradient.

(Bijendra Singh et al. 2013). African rift system shows similar gravity signatures and interpreted density structures (Girdler et al. 1969; Darracott et al. 1972).

Modelling of gravity and magnetic anomalies using constraints from seismic and borehole has brought out the maximum sedimentary thickness of $5.5 \mathrm{~km}$ which is very similar to the results inferred from earlier studies (Singh Paramjit 2000; Jitendra Kumar et al. 2005). G-M modelling has also revealed presence of narrow dykes, which requires upper normal $(29 \mathrm{~N})$, as well as reverse (29R) magnetization direction of Deccan magnetostratigrahy to match the observed magnetic anomalies. It has also revealed presence of highdensity mafic body near the southwestern margin of the basin, which supports the contention of a giant sill proposed by (Choudhary 1977) in this area. This body extends to shallow depth and requires reverse magnetization direction to match the observed magnetic anomalies, which corresponds to the main pulse of Deccan eruption. Lala et al. (2014) have also reported occurrence of large number of volcanic dykes and sills of Deccan origin in this region. Mahanadi rift zone therefore acts as a thin spot (Chalapathi Rao and Lehmann 2011) for the transfer of Deccan magma, which must have brought modification of the lithosphere.

The basin boundary faults are usually the most dominant tectonic structures. Since the SRB evolved largely due to extension across WNW-ESE/ 
NW-SE trending preexisting weak planes confined between two strike-slip faults oriented along the ENE-WSW extension direction. Integration of potential field, RS and geological data clearly reveals that ENE-WSW trend is a dominant structural feature, which coincides with the direction of preexisting Narmada-Son lineament along which basin developed due to strike slip motion in ENE-WSW direction. Presence of linear magnetic anomalies along ENE-WSW direction is associated with Deccan basalts at number of places and hence, emplacement of dykes along ENE-WSW represents post-rift tectonic event due to reactivation of faults. Interestingly, the large mafic dyke swarms of Deccan volcanism in Narmada Tapi region also depicts predominantly ENE-WSW orientation (Wei et al. 2013) and appears to be genetically related to Pachmarhi (Sheth et al. 2009), Sangammer (Bondre et al. 2006), Shahdol, Chirimiri and Umaria (Paul et al. 2008) dykes in Satpura and southern Rewa basins of central India. It is suggested that these dykes are either contemporaneous or late stage intrusions of Deccan magma along the Narmada-Son lineament and were emplaced along intrabasinal faults within the Rewa basin.

Study of lineament pattern also reveals stress distribution and its role in faulting and dyke emplacement (Pollard 1987; Hoek and Seitz 1995; Gudmundsson 1995, 2002; Heeremans et al. 1996; Ray et al. 2007). The ENE-WSW trending lineaments, which are most predominant in this region, are also associated with mafic dykes due to Deccan volcanism. Therefore, the regional minimum compressive stress direction must have been NNWSSE during the emplacement of Deccan magma (Ray et al. 2007; Sheth et al. 2009; Wei et al. 2013), which matches quite well with the extensional regime produced by the $\mathrm{N}-\mathrm{S}$ movement of the Indian plate before the onset of Deccan volcanism (Wei et al. 2013). Therefore, the preexisting basement faults must have been reactivated during the time of Deccan volcanism in this region.

\section{Conclusions}

Interpretation of gravity and magnetic data over the study area has not only brought out the geometry, sedimentary thickness and basement configuration but also deciphered the volcanic sills and dykes intruding the sediments. It has delineated two prominent basins of thick PermoTriassic sediments aligned in the ENE-WSW and WNW-ESE direction in the northern and southern part of the study area respectively. A transverse ridge dissects the southern basin into two sub-basins. Structural analysis of remote sensing and potential field data suggests that the WNWESE trending faults are related to rift formation whereas ENE-WSW trending preexisting lineaments are intruded with Deccan basalt dykes. Therefore, South Rewa Gondwana basin has witnessed post-rift tectonic events due to Deccan volcanism.

\section{Acknowledgements}

We are thankful to the Director CSIR-National Geophysical Research Institute, Hyderabad for his encouragement and permission to publish this work. We thank the reviewer for making constructive suggestions, which significantly improved the manuscript. The study was performed as a part of INDEX project of CSIR-National Geophysical Research Institute.

\section{References}

Agarwal R P, Dotiwala S F and Bhoj R 1993 Structural framework of Son-Mahanadi Gondwana basin based on the study of remote sensing data; Gondwana Geol. Magazine, Spec. Vol., Birbal Sahni Centre, National Symposium Gondwana, India, pp. 207-217.

Bijendra Singh et al. 2009 Gravity and magnetic survey for delineation of tectonic features and basement configuration of South Rewa Basin; Technical Report \#NGRI2009-EXP-702.

Bijendra Singh, Swarnapriya Ch and Nageswara Rao B 2013 Structures and tectonics of Son-Mahanadi rift basin, India derived from joint interpretation of gravity and magnetic data incorporating constraints from borehole and seismic informations; Society of Petroleum Geophysicists (SPG), 10th Biennial International Conference and Exposition, Kochi, 409p.

Biswas S K 1999 A review on the evolution of rift basins in India during Gondwana with special reference to western Indian basins and their hydrocarbon prospects; Proc. Indian Nat. Sci. Acad. 65(A3) 261-283.

Blakely R J 1995 Potential theory in gravity and magnetic applications; Cambridge University Press.

Blakely R J and Simpson R W 1986 Approximating edges of source bodies from magnetic or gravity anomalies; Geophysics 51(7) 1494-1498.

Bondre N R, Hart W K and Sheth H C 2006 Geology and Geochemistry of the Sangamner mafic dyke swarm, western Deccan volcanic province, India: Implications for regional stratigraphy; J. Geol. 114 155-170. 
Bonham Carter G F 1989 Comparison of images analysis and GIS for integration of geosciences maps; Geol. Surv. Canada S9-9 141-155.

Casshyap S M and Tewari R C 1991 Depositional model and tectonic evolution of Gondwana basins; In: Indian Gondwana (eds) Venkatachala B S and Maheswari H K, Geol. Soc. India Memoir 21 95-206.

Cengiz O, Sener E and Yagmurlu F 2006 A satellite image approach to the study of lineaments circular structures and regional geology in the Golcuk Crater district and its environs (Isparta, SW Turkey); J. Asian Earth Sci. 27(2) 155-163.

Chalapathi Rao N V and Lehmann B 2011 Kimberlites flood basalts and mantle plumes: New insights from the Deccan Large Igneous Province; Earth Sci. Rev. 107 315324 .

Chandan Chakraborty, Nibir Mandal and Sanjoy Kumar Ghosh 2003 Kinematics of the Gondwana basins of peninsular India; Tectonophys. 377 299-324.

Chen S and Zhou Y 2005 Classifying depth-layered geological structures on Landsat TM images by gravity data: A case study of the western slope of Songliao Basin, northeast China; Int. J. Remote Sens. 26 2741-2754.

Choudhary A 1977 Tectonic and Palaeogeomorphic evolution of Son-Mahanadi Gondwana basin-belt of Madhya Pradesh, India; 4th Int. Gondwana Symposium, Calcutta, India, 2 786-804.

Cooper G R J and Cowan D R 2006 Enhancing potential field data using filters based on the local phase; Comput. Geosci. 32 1585-1591.

Cordell L and Grauch V J S 1985 Mapping basement magnetization map zone from aeromagnetic data in the San Juan basin, New Mexico; In: The Utility of Regional Gravity and Magnetic Anomaly Maps (ed.) Hinze W E, Soc. Exploration Geophysics, pp. 181-197.

Darracott B W, Fairhead J D and Girdler R W 1972 Gravity and magnetic surveys in northern Tanzania and southern Kenya; Tectonophys. 15 131-141.

Fairhead J D, Salem A, Williams S and Samson E 2008 Magnetic interpretation made easy: The tilt-depth-dip$\Delta k$ method; In: Annual International Meeting Expanded Abstracts, Soc. of Exploration Geophysicists, pp. 779-783.

Fraser A, Huggins P, Rees J and Cleverly P 1997 A satellite remote sensing technique for geological structure horizon mapping; Int. J. Rem. Sens. 18 1607-1615.

GEOSOFT Oasis Montaj 2008 The core software platform for working with large volume gravity and magnetic spatial data; Geosoft Inc, Toronto, Canada.

Girdler R W, Fairhead J D, Searle R C and Sowerbutts T C 1969 The evolution of rifting in Africa; Nature 2241178 1182.

Gudmundsson A 1995 The geometry and growth of dykes; In: Physics and Chemistry of Dykes (eds) Baer G and Heimann A, Balkema, Rotterdam, Netherlands, pp. 2334.

Gudmundsson A 2002 Emplacement and arrest of sheets and dykes in central volcanoes; J. Volcanol. Geotherm. Res. $116279-298$.

Harris J R 1991 Mapping of regional structure of eastern Nova Scotia using remote sensing imagery: Implication for regional tectonics and gold exploration; Canadian J. Rem. Sens. 17 122-135.
Heeremans M, Larsen B and Stel H 1996 Palaeostress reconstruction from kinematic indicators in the Oslo Graben, southern Norway: New constraints on the mode of rifting; Tectonophys. 266 55-79.

Hoek J D and Seitz H M 1995 Continental mafic dyke swarms as tectonic indicator: An example from the Vest fold Hills, East Antarctica; Precamb. Res. 75 121-139.

Jitendra Kumar, Paramjit Singh, Verma N K and Negi M S 2005 Modelling of igneous-prone south Rewa basin an integrated approach; Proceedings of $6^{\text {th }}$ International Petroleum Conference and Exhibition, 15-19 January, New Delhi, pp. 1-6.

Lala T, Chaudhary A K, Patil S K and Paul D K 2011 Mafic dykes of Rewa Basin, central India: Implications on magma dispersal and petrogenesis; In: Dyke Swarms (ed.) Srivastava R K, Springer-Verlag, Berlin, pp. 141162.

Lala T, Mombasawala L S, Pande K and Paul D K 2014 New ${ }^{39} \mathrm{Ar}-{ }^{40} \mathrm{Ar}$ ages of dykes from Madhya Pradesh and Chhattisgarh: Evidence for polyphase dyke intrusion in eastern Deccan Volcanic Province; Curr. Sci. 107 10271032 .

Lamontagne M, Keating P and Perreault S 2003 Seismotectonic characteristics of the lower St. Lawrence seismic zone, Quebec: Insights from geology, magnetics, gravity and seismic; Canadian J. Earth Sci. 40 317-336.

Leech D P, Treloar P J, Lucas N S and Grocott J 2003 Landsat TM analysis of fracture patterns: A case study from the Coastal Cordillera of northern Chile; Int. J. Rem. Sens. 24 3709-3726.

Lillesand T M and Kiefer R W 2000 Remote sensing and image interpretation; 4th edn, John Wiley, New York.

Liu G D, Hao T Y and Liu Y K 1996 The significance of gravity and magnetic research for knowing sedimentary basin; Prog. Geophys. 11 1-15 (in Chinese).

Lunden B, Wang G and Wester K 2001 A GIS based analysis of data from Landsat TM, airborne geophysical measurements, and digital maps for geological remote sensing in the Stockholm region, Sweden; Int. J. Remote Sens. 22 517-532.

Mather P M 1993 Computer processing of remotely sensed images (Chichester, New York, Brisbane, Toronto, Singapore, John Wiley \& Sons).

Miller HG and Singh V 1994 Potential field tilt - a new concept for location potential field sources; Appl. Geophys. 32 213-217.

Mishra D C and Pederson L B 1982 Statistical analysis of potential fields from subsurface reliefs; Geoexploration 90 247-265.

Paul D K, Lala T and Chaudhary A K 2008 Petrology and geochemistry of mafic flows and dykes of eastern Deccan Volcanic province, India; 33rd International Geological Congress, Oslo, Norway.

Pereira A J S C Victoria S Vicente A M P and Neves L J P F 2008 Structural lineaments in a volcanic island evaluated through remote sensing techniques; International Geoscience and Remote Sensing Symposium (IGARSS), Art. No. 4423127, 1632-1635.

Pollard D D 1987 Elementary fractures mechanics applied to the structural interpretation of dykes; In: Mafic Dyke Swarms (eds) Halls H C and Fahrig W H, Geol. Assoc. Canada Spec. Paper 34 5-24. 
Qureshy M N, Subba Rao D V, Bhatia S C, Aravamadhu P S and Subrahmanyam C 1973 Gravity bases established in India by N.G.R.I. Part IV: Geophys. Res. Bull. 11 136152.

Raharimahefa T and Kusky T M 2006 Structural and remote sensing studies of the southern Betsimisaraka Suture, Madagascar; Gondwana Res. 10(1-2) 186197.

Raja Rao C S 1983 Coalfields of India. Vol-III, Coal resources of Madhya Pradesh and Jammu and Kashmir; Geol. Surv. India Bull. Ser. A 45.

Ray R, Sheth H C and Mallik J 2007 Structure and emplacement of the Nandurbar-Dhule mafic dyke swarm, Deccan Traps, and the tectonomagmatic evolution of flood basalts; Bull. Volcanol. 69 537-551.

Richards J A 1993 Remote sensing digital image analysis, an introduction, 2nd edn, Berlin: Springer-Verlag.

Salem A, Williams S, Fairhead J D, Ravat D and Smith R 2007 Tilt-depth method: A simple depth estimation method using first-order magnetic derivatives; The Leading Edge 26(12) 1502-1505.

Salem A, Williams S, Faihead J D, Smith R and Ravat D 2008 Interpretation of magnetic data using tilt-angle derivatives; Geophysics 73 L1-L10.

Sheth H C, Ray J S, Ranjini R, Vanderkluysen L, Mahoney J J, Kumar A, Shukla A D, Das P, Adhikary S and Jana B 2009 Geology and geochemistry of Pachmari dykes and sills, Satpura-Gondwana basin, central India: Problems of dyke-sill-flow correlations in the Deccan traps; Contrib. Mineral. Petrol. 158 357-380.

Singh Paramjit 2000 Inversion of Gravity Data Using Effective Density Contrast in South Rewa Basin; 3rd Confer- ence and Exposition on Petroleum Geophysics, New Delhi, pp. 405-408.

Spector A and Grant F S 1970 Statistical models for interpreting aeromagnetic data; Geophysics 35 293302.

The ERDAS IMAGINE 9.3 On-Line Help System 2008 Leica Geosystems Geospatial Imaging, LLC [Software] (Worldwide Headquarters, 5051 Peachtree Corners Circle, Norcross, GA 30092-2500, USA).

Thompson D T 1982 EULDPH, A new technique for making computer assisted depth estimates from magnetic data; Geophysics 47 31-37.

Veevers J J and Tewari R C 1995 Gondwana master basin of peninsular India between Tethys and the interior of the Gondwanaland province of Pangea; Geol. Soc. Am. Memoir 187 1-73.

Verduzco B, Fairhead J D, Chris M Green and Chris MacKenzie 2004 New insights into magnetic derivatives for structural mapping; The Leading Edge 23(2) 116119.

Wei Ju, Guiting Hou and Hari K R 2013 Mechanics of mafic dyke swarms in the Deccan Large Igneous Province: Palaeostress field modelling; J. Geodyn. 66 7991.

Yassaghi A 2006 Integration of Landsat imagery interpretation and geomagnetic data on verification of deep-seated transverse fault lineaments in SE Zagros, Iran; Int. J. Remote Sens. 27 4529-4544.

Zeinalov G A 2000 Importance of remote-sensing data in structural geologic analysis of oil- and gas-bearing regions of Azerbaijan; Natural Resour. Res. 9 307313. 